\title{
Stratigraphy and integrated facies analysis of the Saalian and Eemian sediments in the Amsterdam-Terminal borehole, the Netherlands
}

\author{
Robert J.W. van Leeuwen ${ }^{1,2}$, Dirk J. Beets ${ }^{2}$, J.H. Aleid Bosch ${ }^{3}$, \\ Adri W. Burger ${ }^{2}$, Piet Cleveringa ${ }^{2}$, Dick van Harten ${ }^{4}$, G.F. Waldemar \\ Herngreen ${ }^{2}$, Rink W. Kruk ${ }^{4}$, Cor G. Langereis ${ }^{5}$, Tom Meijer ${ }^{2}$, \\ Ronald Pouwer ${ }^{2} \&$ Hein de Wolf ${ }^{2}$ \\ 1 corresponding author; e-mail: r.vanleeuwen@nitg.tno.nl \\ 2 Netherlands Institute of Applied Geoscience TNO - National Geological Survey, \\ P.O. Box 80015, NL 3508 TA UTRECHT, the Netherlands \\ ${ }^{3}$ Netherlands Institute of Applied Geoscience TNO - National Geological Survey, \\ P.O. Box 511, NL 8000 AM ZWOLLE, the Netherlands \\ ${ }^{4}$ Faculty of Earth Sciences, Free University, De Boelelaan 1085, NL 1081 HV \\ AMSTERDAM, the Netherlands \\ 5 Department of Geophysics, Faculty of Earth Sciences, University of Utrecht, \\ P.O. Box 80021, NL 3508 TA UTRECHT, the Netherlands.
}

Manuscript received: 24 September 1999; accepted in revised form: 22 April 2000

\begin{abstract}
The Amsterdam glacial basin was a major sedimentary sink from late Saalian until late Eemian (Picea zone, E6) times. The basin's exemplary record makes it a potential reference area for the last interglacial stage. The cored Amsterdam-Terminal borehole was drilled in 1997 to provide a record throughout the Eemian interglacial. Integrated facies analysis has resulted in a detailed reconstruction of the sedimentary history.

After the Saalian ice mass had disappeared from the area, a large, deep lake had come into being, fed by the Rhine river. At the end of the glacial, the lake became smaller because it was cut off from the river-water supply, and eventually only a number of shallow pools remained in the Amsterdam basin. During the early Eemian (Betula zone, E1), a seepage lake existed at the site. The lake deepened under the influence of a steadily rising sea level and finally evolved into a silled lagoon (late Quercus zone, E3). Initially, the lagoon water had fairly stable stratification, but as the sea level continued to rise the sill lost its significance, the lagoon becoming well mixed by the middle of the Corylus/Taxus zone (E4b). The phase of free exchange with the open sea ended in the early Carpinus zone (E5), when barriers developed in the sill area causing the lagoon to become stratified again. During the Late Eemian (late E5), a more dynamic system developed. The sandy barriers that had obstructed exchange with the open sea were no longer effective, and a tidally-influenced coastal lagoon formed.

The Eemian sedimentary history shown in the Amsterdam-Terminal borehole is intimately connected with the sea-level history. Because the site includes both a high-resolution pollen signal and a record of sea-level change, it has potential for correlation on various scales. Palaeomagnetic results show that the sediments predate the Blake Event, which confirms that this reversal excursion is relatively young. The U/Th age of the uppermost part of the Eemian sequence is $118.2 \pm 6.3 \mathrm{ka}$.
\end{abstract}

Keywords: diatoms, dinoflagellates, Eemian stage, foraminifers, late Saalian, molluscs, ostracods, palaeoecology, palaeomagnetics, pollen stratigraphy, radiometric age, Weichselian, western Europe

\section{Introduction}

The term Eemian, introduced by Harting (1874, 1875), is used worldwide to denote deposits formed during the last interglacial stage. In a discussion on the definition of Pleistocene stages and their bound- aries, during the 1995 International Union for Quaternary Science (INQUA) Congress in Berlin, the INQUA Commission on Stratigraphy concluded that detailed information from the type area of the Eemian was needed to decide the issue of the position of the Middle and Late Pleistocene boundary. The - then - 
Geological Survey of The Netherlands (RGD) was approached, and the successor of the RGD, the Netherlands Institute of Applied Geoscience TNO (NITG-TNO), initiated a project in 1997 to gather the information requested.

The term 'Eemian' had been used by Harting to describe marine strata in the subsurface of the Netherlands that were characterized by two mollusc species: Venerupis aurea senescens and Bittium reticulatum. Harting had seen these strata in many boreholes from the Amsterdam and Amersfoort areas and became convinced of their stratigraphical significance. The name was derived from the Eem river, which flows near the city of Amersfoort.

Geologically, the areas surveyed by Harting became known as the Amersfoort and Amsterdam basins. They form part of a series of tongue-shaped, glacial basins that formed at the margin of the Saalian ice mass (Fig. 1). The basins are bordered by icepushed ridges. Glacier surging is thought to have been responsible for their tongue-like shape (e.g., Zagwijn, 1974), but other glacial processes also contributed to their formation (Van der Wateren, 1985). The tongue-basins were major sites of deposition during late Saalian and Eemian times.

Harting (1874, 1875) originally used the term 'Eemian' in a very broad stratigraphical sense. In the 1950s, the RGD drilled the Amersfoort-1 borehole with the intention of proposing the site as the type locality. The term 'Eemian' had already acquired a defi-

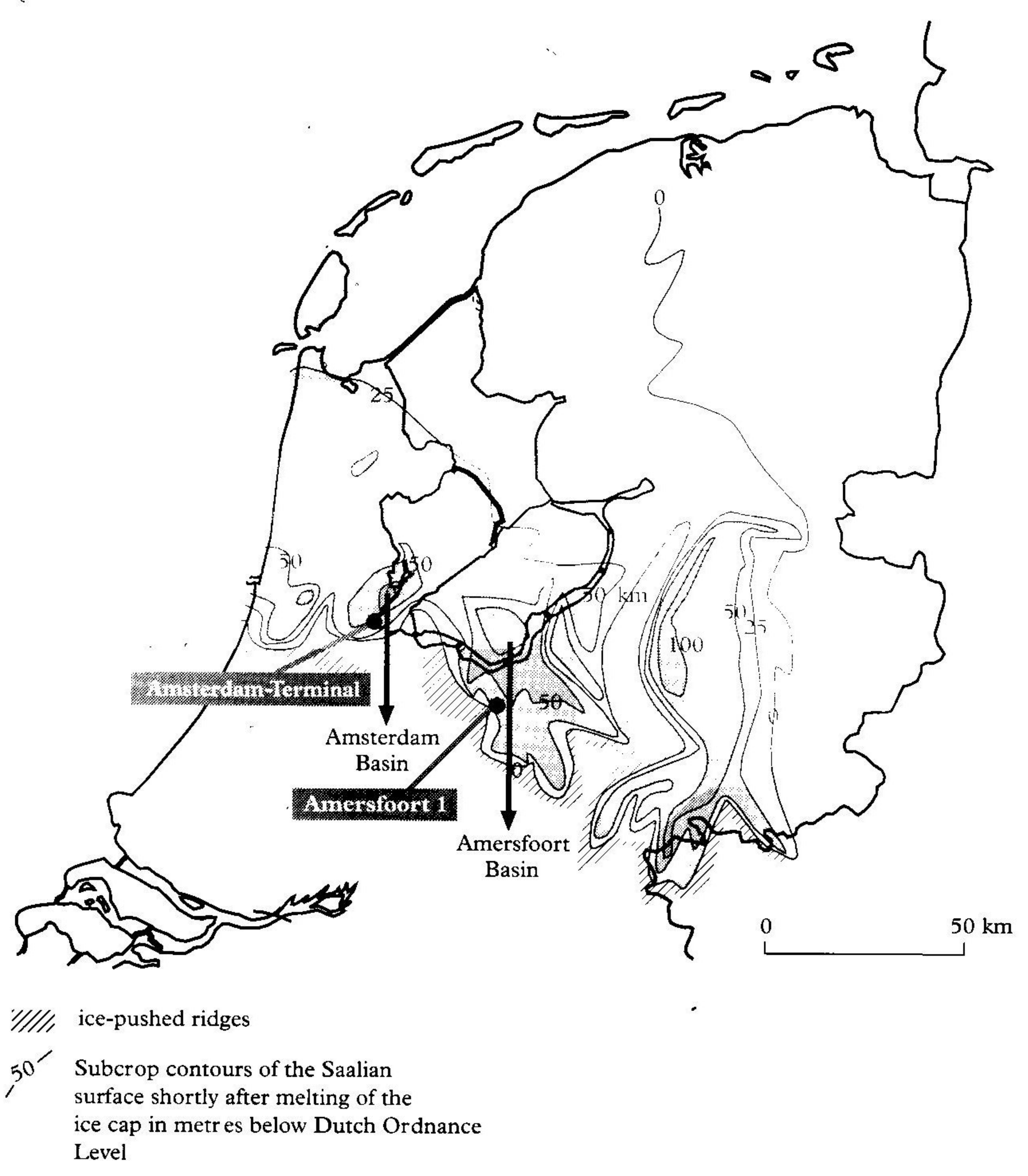

Fig. 1. Saalian glacial basins on-shore in the Netherlands, and the location of the Amsterdam-Terminal and Amersfoort-1 boreholes (after De Gans et al., 2000 - this issue). nite chronostratigraphical and geochronological meaning by then, and had become synonymous with the last interglacial stage. At the time, pollen analysis had become the standard tool in continental Quaternary stratigraphy and the Eemian was understood as the last interglacial before the Holocene, during which the western and central parts of Europe were covered with dense forests.

The Amersfoort-1 borehole was studied using various disciplines, but only papers dealing with the foraminifers (Van Voorthuysen, 1957) and pollen stratigraphy (Zagwijn, 1961) were published - an oversight corrected only recently in the contribution by Cleveringa et al. (this issue). In his paper on Amersfoort-1, Zagwijn (1961) defined a standard pollen zonation for the Eemian in the Netherlands, including data from other localities. This work was very influential and the borehole was often referred to as the unit-stratotype for the Eemian stage. Since the work by Mangerud et al. (1979), the Eemian is correlated with marine isotope substage (MIS) 5.5 (5e).

Zagwijn (1961) had already noted that the Amersfoort-1 interglacial record was incomplete; pollen zone $\mathrm{E} 1$, the first phase in the vegetational development of the interglacial, was missing. As a result of mapping activity, more complete sections were found in the Amsterdam basin, e.g. in the Valkenweg boreholes (Zagwijn, 1983, 1992; De Wolf \& Cleveringa, 1994). In view of the many shortcomings of the Amersfoort-1 sequence (Cleveringa et al., 2000 - this issue), the NITG-TNO decided to collect a borehole from the Amsterdam basin as an additional reference site for the Eemian stage. Considering the high cost, the risk of failure had to be reduced. Thus rather than aiming at the thickest succession of Eemian sediments, the project group selected a site where the probability of recovering a section as complete as that at Valkenweg was high. In June 1997, a borehole was drilled near the passenger terminal in Amsterdam harbour. This borehole was named 'Amsterdam-Terminal' and coded 25E913.

Amsterdam-Terminal is situated at the southern end of the Amsterdam basin, at $52^{\circ} 22^{\prime} 45^{\prime \prime} \mathrm{NL}, 4^{\circ} 54^{\prime} 51^{\prime \prime} \mathrm{EL}$ (Fig. 1); the surface is $1.45 \mathrm{~m}$ above NAP (Dutch Ordnance Datum) and the total depth proved $78.70 \mathrm{~m}$.

The borehole was completely cored and recovery appeared to be very good. After the cores had been Xray photographed, the cores were split and light photographs were taken immediately. One half was lacquered and stored for future reference in the NITGTNO repository. The other half was described, and sampled for specialist studies. Sample depths are given in the present contribution in metres below surface. 


\section{Methods}

Each of the specialists has undertaken detailed analyses, but rather than discussing the results of each group at length an integrated approach is presented here; only palaeomagnetism has been treated separately. Because the Amsterdam-Terminal borehole is a potential reference sequence, the essentials of the relevant disciplines are incorporated as Figures 14-21; complete data sets are available from NITG-TNO.

The pollen-sample preparation method included peptisation using $\mathrm{Na}_{4} \mathrm{P}_{2} \mathrm{O}_{7} \cdot 10 \mathrm{H}_{2} \mathrm{O}$, decalcification with hydrochloric acid (10\%) and acetolysis. A sodium-polytungstate solution (specific gravity 2.1 ) was used for heavy-liquid separation. As a rule, 200-300 pollen grains were counted at each level. Following Jessen \& Milthers (1928), Zagwijn (1961, 1975) established a standard pollen zonation for the Eemian in the Netherlands. He defined the lower boundary of the Eemian as the base of pollen zone E1. Because of the considerable thickness of Eemian sediments in the Amsterdam-Terminal succession, the pollen record reveals much detail. A refined subdivision of the standard zones seems possible, but because the correlative value can not be assessed as yet, only a local zonation

\begin{tabular}{|c|c|c|c|}
\hline \multicolumn{2}{|r|}{ Regional zonation } & \multicolumn{2}{|l|}{ Local zonation } \\
\hline & Pinus, Betula & $\begin{array}{l}\text { Betula, funiperus, } \\
\text { Hippophaë, Artemisia }\end{array}$ & AT 16 \\
\hline E 6a & $\begin{array}{l}\text { Picea, Abies, Alnus, } \\
\text { Carpinus, Quercus, Pinus }\end{array}$ & $\begin{array}{l}\text { Picea maximum, Abies } 3 \% \\
\text { decrease of Carpinus }\end{array}$ & AT 15 \\
\hline \multirow[t]{2}{*}{ E 5} & \multirow{2}{*}{$\begin{array}{l}\text { Carpinus, Quercus, Alnus } \\
\text { Corylus, Picea }\end{array}$} & Carpinus maximum & AT 14 \\
\hline & & $\begin{array}{l}\text { Carpinus }>2 \% \\
\text { Taxus }<5 \%\end{array}$ & AT 13 \\
\hline \multirow[t]{2}{*}{$\mathrm{E} 4 \mathrm{~b}$} & \multirow[t]{2}{*}{$\begin{array}{l}\text { Taxus, Cor ylus, Quercus } \\
\text { Picea, Carpinus }\end{array}$} & $\begin{array}{l}\text { Carpinus }<2 \% \\
\text { decrease of Taxus }\end{array}$ & AT 12 \\
\hline & & Taxus maximum & AT 11 \\
\hline \multirow[t]{2}{*}{ E 4a } & \multirow[t]{2}{*}{ Corylus with Quercus } & $\begin{array}{l}\text { Corylus maximum } \\
\text { Taxus ca. } 1 \%\end{array}$ & AT 10 \\
\hline & & further increase of Corylus & AT 9 \\
\hline \multirow{4}{*}{ E 3} & \multirow{4}{*}{$\begin{array}{l}\text { Quercus } \\
\text { increase of Corylus } \\
\text { decrease of Ulmus }\end{array}$} & increase of Corylus & AT 8 \\
\hline & & $2^{\text {nd }}$ maximum Pinus & AT 7 \\
\hline & & Quercus maximum & AT 6 \\
\hline & & increase of Betula & AT 5 \\
\hline E 2 & $\begin{array}{l}\text { Pinus } \\
\text { low percentage of Quercus, } \\
\text { Ulmus, Fraxinus, Alnus }\end{array}$ & $\begin{array}{l}1^{\text {st }} \text { maximum Pinus } \\
\text { (Ulmus maximum) }\end{array}$ & AT 4 \\
\hline E 1 & Betula, low percentage of Pinus & $\begin{array}{l}\text { Betula } \\
\text { low percentage of Pinus, } \\
\text { funiperus }\end{array}$ & AT 3 \\
\hline \multirow[t]{2}{*}{ LS } & \multirow{2}{*}{$\begin{array}{l}\text { non-arboreal pollen high } \\
------------ \\
\text { reworked pollen }\end{array}$} & $\begin{array}{l}\text { increase funiperus } \\
\text { Artemisia, Cyperaceae, } \\
\text { Gramineae, Helianthemum }\end{array}$ & AT 2 \\
\hline & & Pinus high in the upper part & AT 1 \\
\hline
\end{tabular}

Fig. 2. Correlation between local pollen zonation and standard regional zonation (Zagwijn, 1961, 1975), and main characteristics of the zones. LS refers to Late Saalian, EW to Early Weichselian. is presented here (Fig. 2). Presentation of the data (Fig. 14) follows international conventions; Pediastrum, Hystrichosphaeridae and obviously reworked pollen are not included in the pollen sum.

Diatom samples (1-3 g of sediment) were treated with hydrogen peroxyde (30\%) and hydrochloric acid $(10 \%)$. To eliminate a major part of the clay fraction, each sample was decanted at least eight times with demineralized water. From the remaining suspension, $0.5 \mathrm{ml}$ was pipetted off, dried on a cover slip and mounted in Naphrax. About 200 valves were identified in each sample. A distinction was made between broken and whole frustules (Fig. 15).

Mollusc samples were taken only from intervals in which mollusc shell fragments were visible macroscopically. The size fraction larger than $0.5 \mathrm{~mm}$ was analysed for mollusc and other macro-remains (Figs. 16-17). The counts refer to the number per sample and they are based on the separate analysis of the various fractions $(0.5-0.85,0.85-4.0$ and $>4.0 \mathrm{~mm})$. If a fraction yielded more than approx. 200 specimens, only a split was analysed. For significant environmental parameters, ecograms have been drawn, in which the marine species are grouped according to their preferences; only well preserved specimens have been considered.

The quantitative analysis of the foraminiferal assemblages is based on the fraction larger than $125 \mu \mathrm{m}$ (Fig. 18). A sodium-polytungstate solution (s.g. 1.64) was used to concentrate the foraminifers. The taxonomy of the NW European Late Quaternary faunas is fairly stable. As a rule, the same names are used as by, for instance, Knudsen $(1982,1985)$. The one important exception is the classification of the morphologically complex group of Ammonia species, for which Jorissen (1988) is used.

Dinoflagellate samples (Fig. 19) were processed with hydrochloric acid (20\%) and hydrofluoric acid (approx. 20\%). Sodium polytungstate (s.g. 2.1) was used as a medium for heavy-liquid separation (see Munsterman \& Kerstholt, 1996) and the organic residue was sieved $(20 \mu \mathrm{m})$ to concentrate the dinoflagellate cysts. Information on the ecology of species is derived from De Vernal et al. (1992), Edwards \& Andrle (1992) and Harland (1983).

A qualitative analysis of the ostracod assemblages in the fraction larger than $125 \mu \mathrm{m}$ was made (Fig. $20)$. The numbers present did not allow quantitative treatment.

The 63-500 $\mu \mathrm{m}$ heavy-mineral fraction was studied (Fig. 21). Samples were treated with hydrochloric acid $(25 \%)$ and nitric acid $(50 \%)$ to remove any coating of the grains, and a sodium-polytungstate solution (s.g. 2.87) was used to separate the heavy minerals. 
The grains were then embedded in Canada balsam. Two hundred transparent grains were counted per sample by line counting.

The fine gravel (3-5 mm) of two samples from the lowermost core was analysed quantitatively to determine its components (cf. Zandstra, 1978).

Palaeomagnetism samples were taken approximately every $50 \mathrm{~cm}$ by using $8 \mathrm{~cm}^{3}$ perspex cylinders, yielding a total of 93 standard-sized samples (specimens) from the 31-76 m depth interval (Fig. 9). Fine-grained sediments like clays and silty clays were sampled; sandy intervals were avoided. The natural remanent magnetisation (NRM) of each specimen was demagnetized using alternating fields (AF) with small steps of 3, 5 or $10 \mathrm{mT}$, and typically up to $60-75 \mathrm{mT}$. A small viscous (laboratory) component was usually removed at very low fields of $3 \mathrm{mT}$. Occasionally, fields of up to $150 \mathrm{mT}$ were needed, particularly in the lowermost cores. The demagnetization records suggest that magnetite is the main carrier of the remanence, although an Fe sulphide (greigite) cannot be excluded on the basis of AF demagnetization alone. To conserve specimens for additional rock-magnetic experiments, thermal treatment has still to be performed.

Grain-size was measured, after removal of carbonates and organic matter, by laser diffraction using a Malvern Mastersizer-X. The clay fraction refers to all particles smaller than $8 \mu \mathrm{m}$ (cf. Konert \& Vandenberghe, 1997).
Analysis of major and trace elements was performed on ground whole-rock samples using X-Ray Fluorescence (ARL8410). Carbon and sulphur were measured using an Strohlein CS mat 5500 element analyzer. The organic carbon, carbonate and sulphur content are given in dry-weight percentages.

A set of six clay samples was measured by X-ray diffraction (Philips PW 1820/PW 1710) in the Laboratory of Soil Science and Geology at Wageningen University.

The U/Th disequilibrium dating method has been applied to obtain an age estimate for the top of the Eemian sequence. Pristine shells of a mollusc, Venerupis aurea senescens, were analysed. Cogenetic samples of this species were step-wise leached using acetic acid $(2.5 \mathrm{~N})$ and nitric acid $(7 \mathrm{~N})$. To correct for the presence of a detrital component, which is indicated by the presence of non-soluble ${ }^{232} \mathrm{Th}$, the Osmond et al. (1970) isochron method was applied. The age was calculated according to the method of Ludwig \& Titterington (1994). To reduce the error in the estimated age, a robust biweight average using Ludwig's Isoplot programme was calculated.

\section{Saalian sediment units}

The characteristics of the four Saalian sedimentary units that have been distinguished, are shown in Figure 3.

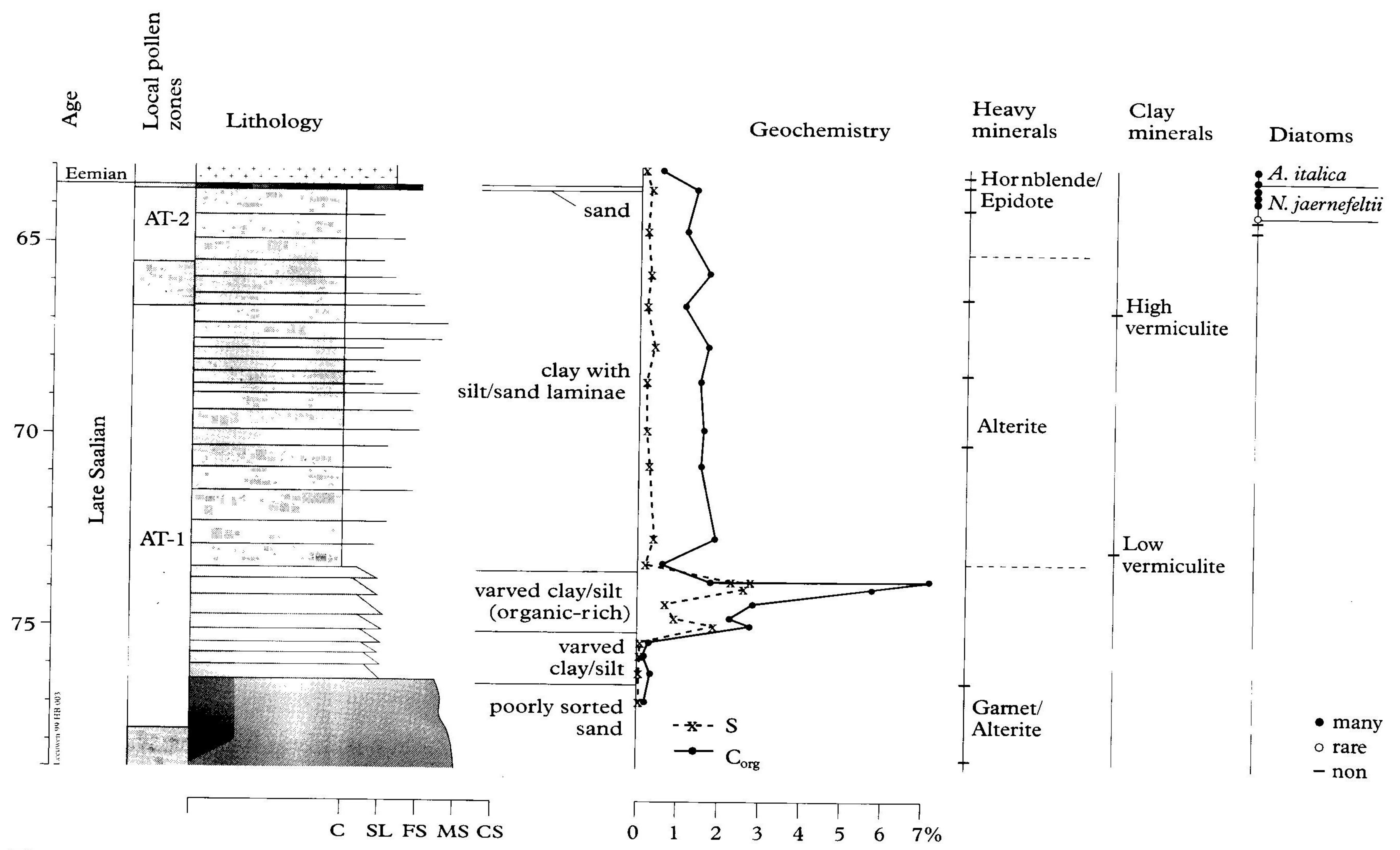

Fig. 3. Stratigraphy, lithology and characteristics of the Saalian interval in the Amsterdam-Terminal borehole. Sample levels for the various analyses are indicated; depths in metres below surface. 
The lowermost unit consists of brownish grey, poorly sorted sands with scattered fine gravel and silty clay clasts. The heavy-mineral content, characterized by a high proportion of garnet $(22-34 \%)$, a relatively high proportion of volcanic minerals $(2.5-5.5 \%)$ and a relatively low proportion of alterite $(10 \%)$, does not match any of the assemblages that characterize the Pleistocene formations of the Netherlands. It is a mixture from several sources which, as indicated by the high proportion of volcanics, include sediments deposited by the Rhine. Gravel analysis corroborates this interpretation. The gravel in the lowermost part of the unit is a mixture of Rhine-supplied fissured quartz, material transported by the so-called 'eastern rivers' (transparent quartz) and some Scandinavian material. The gravel at the very top is angular and consists only of Scandinavian components; it has the same composition as the Saalian diamictons (type DgIVb of Zandstra, 1978).

The sediment contains only pollen. The spectra are characterized by a high proportion of pollen that can be identified as reworked from much older deposits, in particular of Tertiary age (e.g., Taxodium and Sequoia). A contemporaneous component cannot be recognized.

\section{Varved clay and silt (76.45-75.15 m)}

The upper boundary of the poorly sorted interval is sharp, and the next unit consists of normally graded laminae of sandy silt and silty clay, interpreted as varves. Solemarks are locally visible. Approximately sixty varves were counted; their thickness diminishes upwards from a centimetre to a millimetre scale. Both the organic carbon $(0.18-0.27 \%)$ and sulphur (0.05$0.1 \%$ ) content are very low. Heavy-mineral analysis has not been carried out.

The varved interval has the same pollen content as the sands at the base (see above).

\section{Organic-rich varved clay and silt (75.15-73.55 m)}

At $75.15 \mathrm{~m}$, the colour of the varves changes into dark greyish brown. About ninety varves were counted; they are each generally several centimetres thick. The varves are very rich in organic carbon (1.7-7.2\%) and sulphur $(0.6-2.7 \%)$. The carbonate content is also very high (up to $41.6 \%$ ), except in the uppermost sample $(8 \%)$. Heavy-mineral analysis has not been carried out.

The varved interval has the same pollen content as the sands at the base (see above).
From $73.55 \mathrm{~m}$ upwards, the varves gradually disappear and the sediment changes into a greyish green clay with thin layers of silt and sand that lack macroscopically visible grading. The thickness of the layers varies from several millimetres to several centimetres. Small, round holes - thought to represent gas-filled cavities - occur. The upper ten centimetres of the interval consist of a greyish-green fine sand that contains some fine gravel. The organic carbon content of the clay is commonly $1.1-1.5 \%$, and the sulphur content is $0.14-0.3 \%$. The carbonate content is fairly high (commonly $10-20 \%$ ).

The heavy-mineral content is different from that of the poorly sorted sands at the base of the section. In the samples below $65 \mathrm{~m}$, the assemblage is characterized by relatively high frequencies of alterite (15$21 \%$ ), indicating an increased contribution by Rhine sediments. In the top of the clay, the alterite proportion is much lower, and the assemblage is dominated by hornblende and epidote. The sand layer at the top has a similar mineralogy but is further characterized by a high proportion of garnet. The hornblende/epidote assemblage is of Scandinavian origin but cannot be considered in any way typical of glacial sediments. It is the predominant mineralogy in the Neogene sediments of the eastern parts of the North Sea Basin (Bijlsma, 1981). In the Netherlands, it characterizes deposits from the eastern rivers as well as the Neogene and Quaternary marine sediments.

The clay mineralogy also changes through this unit. It is poor in vermiculite at the base of the interval and rich at the top.

The lower part of the interval is still within local pollen zone AT- 1 . The very top of zone AT-1 stands out because of its high percentages of Pinus pollen. The abundance of clearly reworked pollen significantly decreases between 66.60 and $65.60 \mathrm{~m}$, and the upper part of the clay is characterized by high percentages of non-arboreal pollen, e.g. Artemisia, Cyperaceae and Gramineae (local zone AT-2). These spectra are considered to represent an essentially contemporaneous signal and record the presence of treeless tundra with patches of Juniper. It is interpreted as late Saalian. At two levels (65.61-65.64 and 65.03-65.06 m), remnants of a moss, Amblystegium riparium, have been found. This species has a wide geographical distribution, but flourishes nowadays in central and southern Sweden. It grows at wet sites and even in ponds.

From $64.07 \mathrm{~m}$ upwards, the sediment contains diatoms. The assemblage is typical of high-latitude, fresh-water situations and is characterized by high 
proportions of Navicula jaernefeltii, Fragilaria pinnata and Amphora pediculus. The assemblage is known from the uppermost Saalian from other boreholes in the western part of the Netherlands (see, among others, De Wolf \& Cleveringa, 1994). N. jaernefeltii, a tiny and fragile species, lives at present at the bottom of shallow pools at depths of 0.5 metres or less (Foged, 1974) under oligotrophic conditions (Stoermer, 1980).

\section{Eemian sediment units}

The characteristics of these units are shown in Figures 4-8.

\section{Light-coloured diatomite (63.50-61.95 m; Fig. 4)}

The lowermost unit of the Eemian consists of a laminated greyish green diatomite that contains little organic carbon (0.3-0.5\%) and sulphur (0.03-0.07\%). Grain-size analysis shows that much of the diatom assemblage falls within the sand and silt fractions. Although the clastic component is subordinate, sufficient grains are present for heavy-mineral analysis. The composition is similar to that of the uppermost Saalian sediments and the main part of the overlying Eemian sediments, hornblende and epidote being the dominant minerals.

The base of the Eemian stage is placed at $63.5 \mathrm{~m}$. The interval comprises five local pollen zones (AT37). The lowermost two are the equivalents of the standard regional zones E1 and E2, characterized by pre- dominance of Betula and Pinus, respectively. The other three represent the lower part of E3, the Quercus zone. The lower zone, AT-5, is distinct because of its high proportion of Betula. AT-6 covers the maximum of Quercus, and AT-7 - which refers to a single spectrum - is characterized by a high proportion of Pinus pollen.

The diatom flora is a fresh-water assemblage dominated by a planktic species, Aulacoseira italica. Other characteristic elements are Stephanodiscus astrea and Cyclotella comta. The assemblage suggests deposition in an oligo- to mesotrophic lake. The diatoms have been well preserved and show no signs of dissolution, which suggests that the bottom water was saturated with respect to biogenic opal all year-round.

In the upper part of the interval, dinoflagellate cysts occur at $62.07 \mathrm{~m}$. It is a very poor and monospecific assemblage consisting of heterotrophic dinoflagellates of the Brigantedinium plexus. Their presence indicates high nutrient levels in a restricted environment.

Foraminifers, ostracods and molluscs are not present in this sediment unit.

Sandy diatomite $(61.95-61.80 \mathrm{~m})$ and dark-brown diatomite (61.80-61.0 m) (Fig. 4)

Overlying the light-coloured diatomite lies a thin layer of greyish-brown sandy diatomite. In its top part, the sand content decreases and the sediment gradually changes into dark-brown diatomite: the so-called 'Harting layer', a well-known marker bed in the Ams-

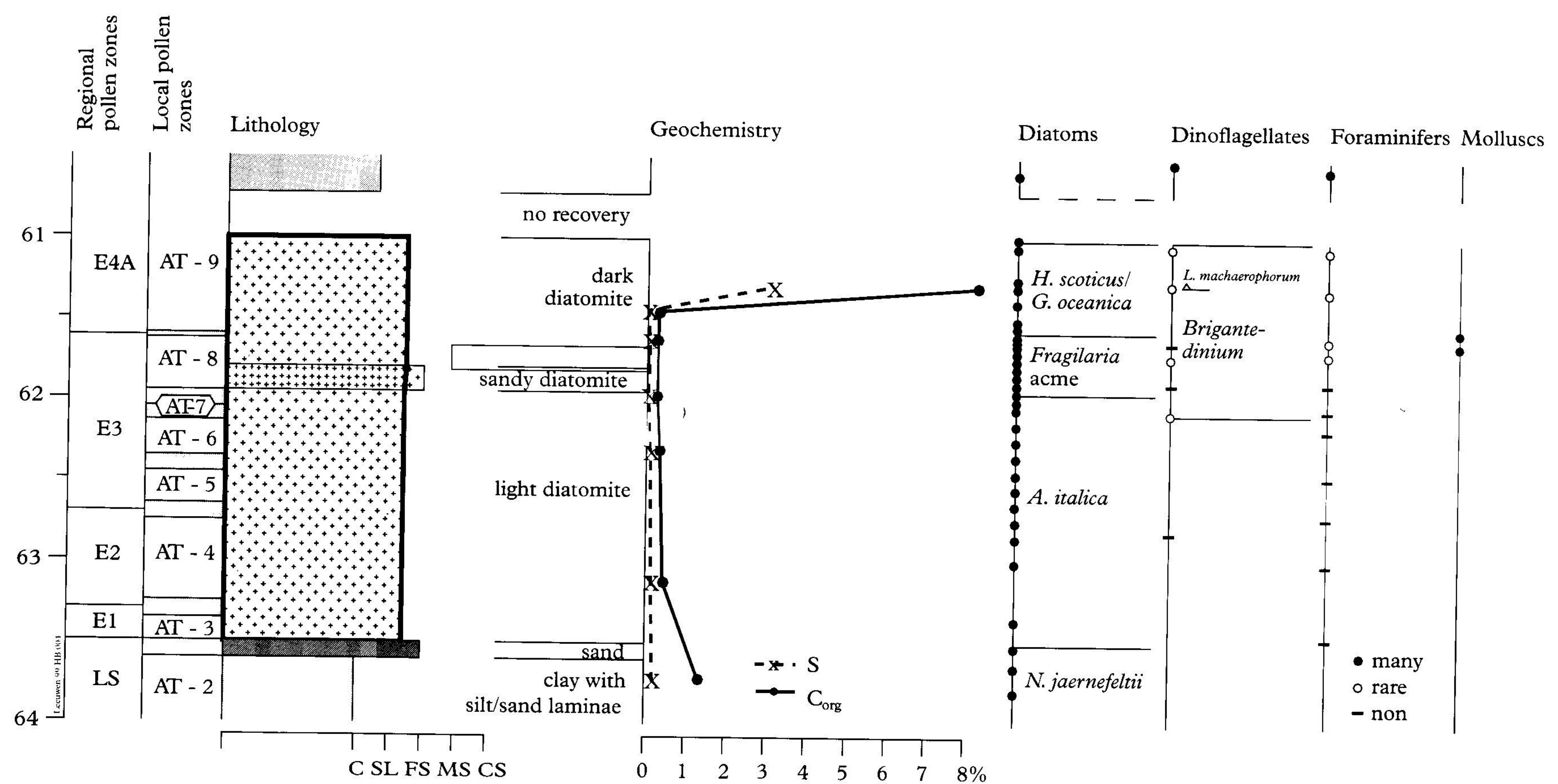

Fig. 4. Stratigraphy, lithology and characteristics of the 60.5-64 $\mathrm{m}$ below surface interval in the Amsterdam-Terminal borehole. Sample levels for the various analyses are indicated. 
terdam basin (Zagwijn, 1983). The sandy diatomite contains little organic carbon $(0.25 \%)$ and sulphur $(0.03 \%)$ and the same holds for the lower part of the dark-brown diatomite. The upper. part of the darkbrown diatomite is very rich in organic carbon $(8.6 \%)$ and sulphur $(3.2 \%)$. This Harting layer contains a few small pieces of wood. Heavy-mineral analysis was not carried out for this unit.

The interval covers local pollen zone AT- 8 and part of AT-9. The boundary between these zones corresponds with the boundary between regional pollen zone E3 and E4a. Zone AT-8 forms part of the Quercus zone, characterized by a decrease of Pinus and a marked increase in Dryopteris and non-arboreal pollen, in particular Gramineae and Cyperaceae. AT8 is further characterized by peak abundances of Pediastrum.

The diatoms show a distinct succession, also known from other boreholes, e.g. Amsterdam-Valkenweg (De Wolf \& Cleveringa, 1994). The assemblage at the base of the interval is still the same $A$. italica flora as found in the light-coloured diatomite below. Between 61.90 and $61.60 \mathrm{~m}$, the flora is characterized by high percentages of the fresh-water genus Fragilaria. The first marine and brackish marine forms (viz. Synedra tabulata, Hyalodiscus scoticus and Cocconeis scutellum) are found within this predominantly freshwater assemblage. In the upper part of the interval, Fragilaria species disappear and Hyalodiscus scoticus and Grammatophora oceanica become the most important species. The latter assemblage is known from Eemian deposits in the Netherlands (De Wolf \& Cleveringa, 1994) and in the Baltic region (Brockmann, 1928; Grönlund, 1991). It is considered characteristic of a brackish marine to marine environment with little or no tidal influence, clear water and a vegetation of seaweed.

Dinoflagellate cysts are rarely found in the lower part of the interval but they become fairly common towards the top. The assemblage is initially very similar to the one of the underlying unit but, as the number of specimens increase, it changes into a more diverse lagoonal assemblage. In addition to the still abundantly occurring Brigantedinium, species such as Diplopelta symmetrica, Tuberculodinium vancampoae and Lingulodinium machaerophorum are present. The last species is represented by a variety characteristic of brackish water. The abundance of $T$. vancampoae and $L$. machaerophorum is of interest from a climatic point of view. These species are characteristic of (sub)tropical waters and their presence corroborates the general view that Eemian water temperatures were higher than those during the Holocene.

Poor assemblages of benthic foraminifers are pre- sent between 61.73 and $61.33 \mathrm{~m}$; the top of the interval is virtually barren. A diverse assemblage predominated by Elphidium excavatum, a relatively deep living species, occurs in the lowermost sample. The assemblage is fairly heterogeneous and includes shallow living brackish-water species such as Ammonia parkinsoniana tepida, as well as marine species, i.e. Cibicides spp. and Quinqueloculina seminula. Higher up, a completely different assemblage occurs consisting mainly of the brackish-water species Elphidium gunteri and Nonion germanicum, two species that flourish at present-day mudflats.

Fragmented though well preserved molluscs occur between 61.65 and $61.57 \mathrm{~m}$. The assemblage is a mixture of sublittoral and littoral species. Species indicative of lowered salinities, including epiphytes such as Turboella radiata balkei and Bittium reticulatum, predominate. The fragmentation is thought to be due to the coring process.

No recovery (61.0-60.70)

No sediments were recovered from a $30-\mathrm{cm}$ interval between 61.0 and $60.70 \mathrm{~m}$.

\section{Laminated silty clay (60.70-53.95) (Fig. 5)}

The diatomaceous interval is covered by a black to dark-green, firm silty clay which is distinctly laminated. The lamination is the result of differences in colour rather than in grain size. Preliminary results from research performed on the same facies at another site in the Amsterdam basin (De Wolf, pers. comm.) indicate that the laminae differ in their diatom content: dark laminae contain more diatoms and have a higher proportion of lagoonal species than light ones. The clay commonly contains minor amounts of sand $(<5 \%)$ and much organic carbon (approx. 1.4-2.9\%) and sulphur (approx. 1.1-2.0\%). The heavy-mineral content is a hornblende/epidote assemblage, similar to that of the light-coloured diatomite.

The laminated clay covers the upper part of local zone AT- 9 , and AT- 10 and AT- 11 . The boundary between AT-10 and AT 11 is the boundary between regional zone E4a, the Corylus zone s.s., and E4b, the Corylus-Taxus zone. Local zone AT-9 is characterized by low abundances of Pediastrum and gradually decreasing amounts of Dryopteris and non-arboreal pollen. Single grains of Taxus are locally found. AT-10 represents the peak interval of Corylus. Taxus gradually becomes a consistent, but still minor element of the assemblages. AT- 11 has high proportions of Taxus and is further characterized by extremely low percentages of Pinus. 


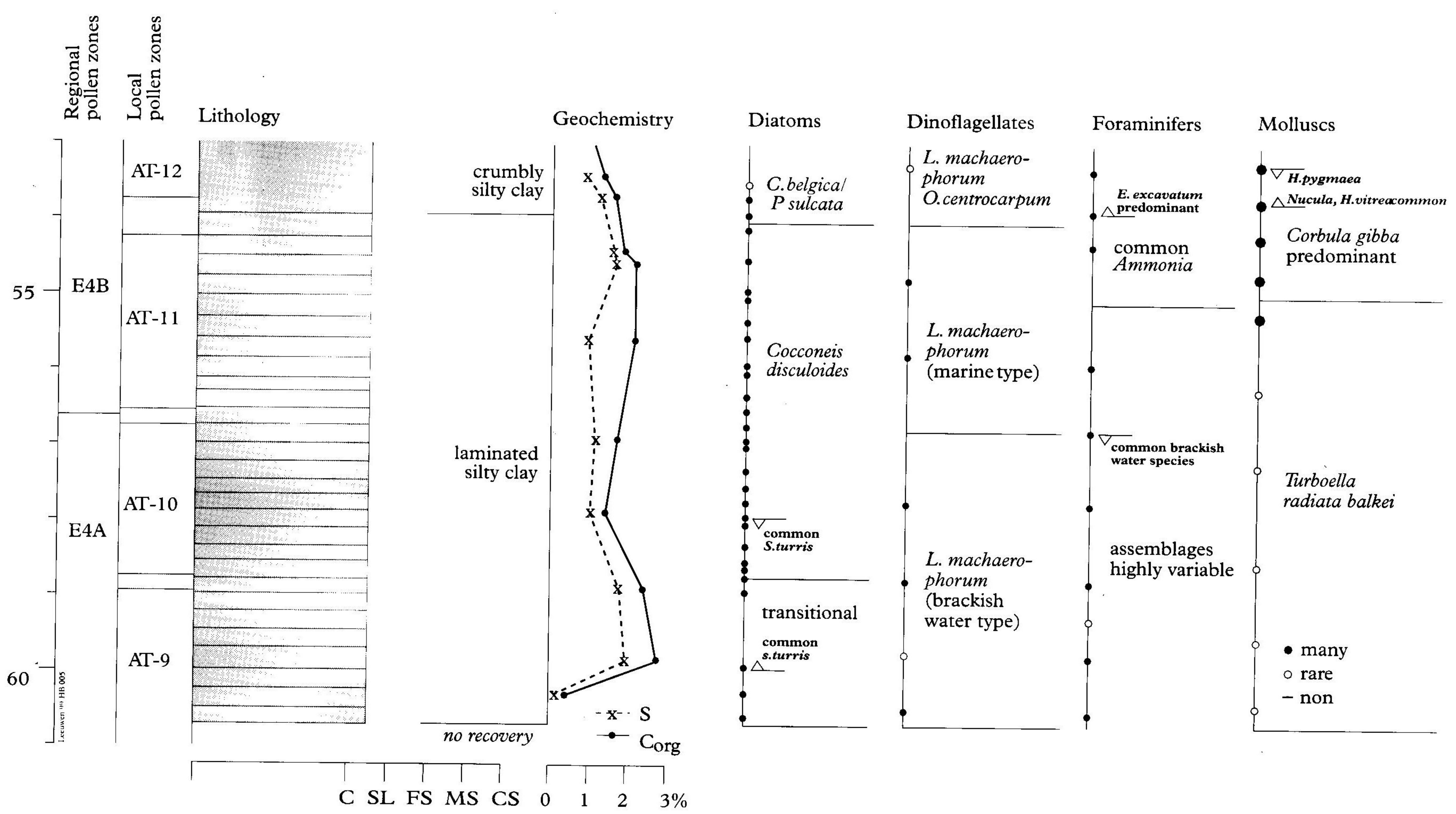

Fig. 5. Stratigraphy, lithology and characteristics of the 53-61 m below surface interval in the Amsterdam-Terminal borehole. Sample levels for the various analyses are indicated.

The diatom flora gradually changes into an assemblage typified by the abundance of Cocconeis disculoides and the occurrence of resting spores of Stephanopyxis turris. Other characteristic elements are Chaetoceros spores, Paralia sulcata, Thalassionema nitzschioides, Thalassiosira decipiens and T. nordenskioeldii. Cocconeis disculoides has similar requirements as $H$. scoticus, and the assemblage indicates that the environment had become comparable to that of the modern western Baltic Sea. The presence of Thalassiosira nordenskioeldii is of interest as this is an arcto-boreal species with a temperature optimum of $2.3^{\circ} \mathrm{C}$ (CleveEuler, 1951). It flourishes in polar waters during spring bloom (Paasche, 1975; Cremer, 1998). The percentage of resting spores of Stephanopyxis turris decreases upwards. Stephanopyxis turris is an oceanic species that forms resting spores under unfavourable conditions and the decreasing percentages are taken as an indication of a gradually increasing open-marine influence.

The assemblages of dinoflagellate cysts show little change across the boundary between the dark-brown diatomite and the laminated clay. Towards the top, changes in the morphology of $L$. machaerophorum are observed that are associated with an overall salinity increase. Below $57.76 \mathrm{~m}$, only the brackish-water morphotype occurs, but above $55.80 \mathrm{~m}$ virtually only the normal-marine variety is found. An increasing influence of the open sea is also indicated by the appearance of Bitectatodinium tepikiense, Lejeunecysta oli- $v a$ and L. sabrina in the upper part of the unit.

Foraminifers occur abundantly in almost all samples. Major taxa are Buccella frigida, Elphidium excavatum (predominantly selseyense type), Elphidium albiumbilicatum, Nonion germanicum and a taxon that seems transitional between the two last-mentioned species, viz. E. cf. albiumbilicatum. The composition of the faunas is extremely variable, and the only common feature seems to be the virtual absence of Ammonia.

The faunal changes are distinguished using three components. Nonion germanicum, E. albiumbilicatum and the intermediate taxon are considered to represent a shallow, brackish-water component. In contrast, $E$. excavatum is interpreted as a deeper-water taxon. This species is eurytopic and is typically common at a depth of several tens of metres. Buccella frigi$d a$ forms the third component. Evidence on its distribution from the Eemian in the Netherlands suggests that it thrives at intermediate depths.

The proportion of the various components varies strongly and, as far as the deep- and shallow-water components are concerned, at random. As periodic variation in water depth is not considered a likely option, the lack of a pattern could mean that the shallow-water component has been displaced. Another interpretation is preferred, however. Lutze (1965) studied the present-day distribution of foraminifers in the western Baltic Sea. He found that E. albiumbilicatum thrives above the thermocline, while the cold-wa- 
ter variety of $E$. excavatum is abundant below it. In view of Lutze's data, the variation in the shallow- and deep-water components is attributed here to periodic change in the depth of the thermocline.

Superimposed on the random changes, the percentages of Buccella frigida show an overall upwards decrease. This decrease may well be interpreted as the result of a deepening of the water; the virtual disappearance of the shallow-water component at the top of the interval supports this interpretation. It should, however, be noted that the presence of B. frigida, although ubiquitous in the Eemian of the Baltic region and locally abundant in the Eemian of the North Sea area (Lafrenz, 1963; Knudsen, 1985), is remarkable. Buccella frigida is a (boreo-)arctic species (Konradi, 1976). It may be common in temperate regions. A well-documented example from mid-latitudes is its occurrence in shallow bays in NE Japan (Matoba, 1970 ). Because the water in the bays has very low temperatures during winter (January, $1-3^{\circ} \mathrm{C}$ ), B. frigi$d a$ is considered a cold-water species.

Molluscs are rare in the lower part of the interval. The poor assemblages are characterized by a predominance of Turboella radiata balkei. Much richer assemblages occur in the upper part. The composition is initially similar to that of the poorer assemblages, but this changes in the uppermost part of the interval, where a Corbula gibba-dominated assemblage occurs. The change is thought to reflect an increase in water depth. Turboella radiata balkei is an epiphytic species associated with Zostera (eelgrass), and is therefore considered to indicate relatively shallow water. By contrast, Corbula gibba lives in deeper water. Fragments of Zostera leaves have been found only in the samples in which molluscs are common.

Crumbly, homogeneous silty clay (53.95 - approx. 48.35 m) (Fig. 6)

The laminated clay gradually changes into a green, homogeneous and very firm silty clay. The clay has a peculiar crumbly texture. In terms of grain size, a close resemblance to the laminated clay is present, and the heavy-mineral assemblages are also very similar. Geochemically, the samples above $53 \mathrm{~m}$ contain less organic matter (1.0-1.2\%) and sulphur (0.5$0.7 \%$ ) than the samples below $53 \mathrm{~m}$, which show transitional values.

The crumbly clay covers local pollen zone AT- 12 and the lowermost part of AT-13. The boundary equates with that between the Corylus/Taxus regional pollen zone and the Carpinus zone. Zone AT-12 is distinguished from AT-11 by the significantly higher abundances of Dryopteris and non-arboreal pollen, in particular Gramineae and Chenopodiaceae. Local zone AT-13 shares these features.

This interval is poor to very poor in diatoms. The assemblages are generally dominated by robust forms

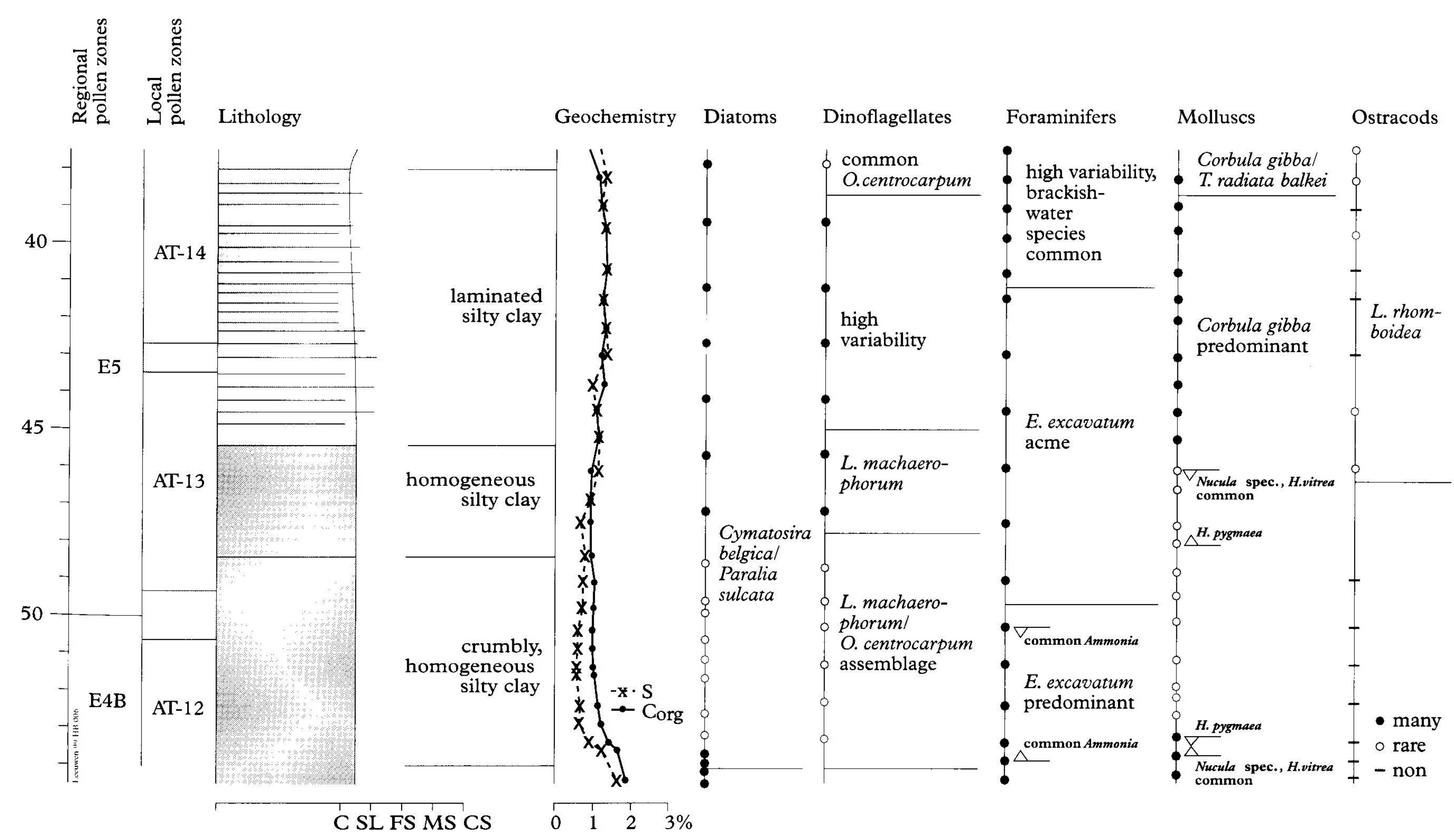

Fig. 6. Stratigraphy, lithology and characteristics of the 38-54 $\mathrm{m}$ below surface interval in the Amsterdam-Terminal borehole. Sample levels for the various analyses are indicated. 
such as Paralia sulcata and are thought to be a relict of severe dissolution. Of particular importance for the interpretation of the assemblages is the occurrence of Nitzschia navicularis and Cymatosira belgica. The former is characteristic of swamps and mudflats, whilst Cymatosira belgica is a species well known from Holocene coastal lagoonal sediments in the Netherlands, in which it is considered to indicate open-marine influence. It is only intermittently present but, since it is a non- robust species, this irregularity may be attributed to dissolution.

The assemblages of dinoflagellate cysts differ from those in the upper part of the laminated clay in only a minor respect. The Brigantedinium group tends to reach lower frequencies, whereas Operculodinium centrocarpum is more abundant. This change indicates a shift towards more open-marine conditions.

Foraminifers are abundant throughout the interval. Their diversity is low; the shallow-water species $B$. frigida, E. albiumbilicatum and $N$. germanicum are practically absent, and the assemblages consist almost solely of Elphidium excavatum and Ammonia parkinsoniana. The former species predominates in all samples, and the frequencies of the latter decrease upwards. This trend reflects a deepening of the water. There are no clear indications of lowered salinity.

Molluscs are common in the sediments below $53 \mathrm{~m}$ and become rare higher in the sequence. The assemblages show a strong resemblance to the Corbuladominated fauna of the upper part of the laminated clay lower in the section. The persistent occurrence of Nucula sp. and Hyala vitrea suggests, however, that the water depth must have increased, since the latter species is known only from depths exceeding $10 \mathrm{~m}$ (Fretter \& Graham, 1978). The samples contain virtually no epiphytic species nor fragments of Zostera leaves. A peculiar aspect of the main part of the interval is the absence of a scavenger species, Hinia pygmaea. The absence of this mollusc may be taken as an indication of decreased levels of consumable organic matter in the sediment.

Homogeneous silty clay (approx. 48.35-45.45 m) (Fig. 6)

The crumbly clay gradually looses its peculiar appearance upwards and changes into an homogeneous, silty clay. The clay has a relatively high sand content and an organic matter content of about $0.9 \%$ throughout, whereas the sulphur content varies between 0.7 and $1.05 \%$. The heavy-mineral assemblage is the same as in the crumbly clay beneath.

The clay falls within local pollen zone AT-13, and thus within regional pollen zone E5, the Carpinus zone.
The clay contains more diatoms than the underlying crumbly clay and their number increases upwards. The preservation of the frustules is good and relatively fragile species are well represented. The assemblage is characterized by Cymatosira belgica. Other quantitatively important species are Paralia sulcata, Rhaphoneis surirella, $R$. amphiceros and $R$. minutissima. The difference with the Paralia sulcata-dominated assemblage of the crumbly clay is interpreted as a mere dissolution effect.

The assemblage of dinoflagellate cysts is slightly different from the flora of the crumbly clay. Lingulodinium machaerophorum is relatively abundant and Operculodinium centrocarpum is relatively rare.

Foraminifers are fairly common. The assemblage is the same Elphidium excavatum-dominated fauna that characterizes the crumbly clay.

Molluscs are scarce and the fauna is also very similar to that of the crumbly clay, but the scavenger, Hinia pygmaea, does occur. Relatively many Abra niti$d a$ are found in the topmost sample, together with some species that are associated with Zostera; the leaves of which are found in all samples of this unit.

At the top of the unit, the first ostracods, Loxoconcha rhomboidea, occur, a species with a strictly phytal habitat.

\section{Laminated silty clay (45.45-38.00 m) (Fig. 6)}

Around $45.45 \mathrm{~m}$, faint laminations appear, and the lithology changes upwards into a laminated, green and firm silty clay. As in the lower laminated interval, the lamination seems to result from colour rather than grain-size differences, but silt and sand laminae do occur, as well as very thin layers of shell debris. At the base of the interval, the clay contains relatively abundant sand (approx. 10\%), but upwards the proportion of sand decreases to $2-3 \%$. This unit represents the most clay-rich interval of the interglacial sequence at this site. The organic matter content increases upwards from $0.9 \%$ to $1.3 \%$, and the same holds for the sulphur content, which lies within the same range. The heavy-mineral assemblage is again characterized by high percentages of hornblende and epidote, except in sample 39.58-39.51 m. The latter yields a high garnet content ( $54 \%$ ).

The laminated clay occurs within the upper part of local pollen zone AT-13 and the lower part of zone AT-14. Carpinus is continuously present in AT-13, but at very low frequencies. AT-14 is the peak interval of Carpinus, with abundances exceeding $10 \%$.

The laminated clay contains the same diatom flora as the homogeneous clay below. The dinoflagellate cyst assemblages are similar, but a particular aspect is 
their high variability. The proportions of Lingulodinium machaerophorum and Diplopelta symmetrica strongly fluctuate.

Foraminifers are generally common. In the lower half of the unit, the assemblage is the same as in the homogeneous clay beneath. There is a distinct difference, however, between the faunas below and above $41 \mathrm{~m}$. Above $41 \mathrm{~m}$, the assemblages are characterized by relatively high abundances of Buccella frigida, Elphidium translucens and Nonion germanicum. Elphidum excavatum is less abundant than below and the percentages tend to decrease upwards. Superimposed on this trend, the frequencies fluctuate wildly, and the same applies to Nonion germanicum. The overall change in the fauna indicates a shallowing of the environment. The strong fluctuations near the top are ill understood but are comparable to those seen in the lower laminated clay.

In comparison with the homogeneous clay, molluscs are more common and their number increase upwards. The difference in the faunal assemblages is small. Corbula remains dominant in most of the samples, but Nucula spp. and Hyala vitrea are much less abundant, whereas Turboella radiata balkei is more common. The proportion of the latter species increases towards the top, where it gradually replaces Corbula gibba as the dominating species. The differences show that the environment was shallowing through the time-span represented by this unit. Zostera leaves occur in almost all the samples.

Ostracods occur only rarely below $40 \mathrm{~m}$ but are more common in the upper part of the interval. Loxoconcha rhomboidea is the most abundant species. The
$L / R$ valve ratio and the presence of both adults and juveniles in the sediments suggest that the species is autochthonous. The only other species found in the interval is Palmoconcha guttata, a species often associated with low-oxygen conditions.

\section{Silty clay coarsening upwards (38.00-32.65 m) (Fig. 7)}

At about $38 \mathrm{~m}$, the clay looses its laminated character and becomes more sandy. Distinct layers of sand are intercalated, and both their number and thickness increase upwards. The organic-matter content as well as the amount of sulphur are lower than in the underlying unit, and both decrease upwards. The heavy-mineral assemblage remains dominated by hornblende and epidote, but the proportion of alterite increases upwards. This increase is probably a grain-size effect.

The unit falls within local pollen zone AT-14, which represents part of the Carpinus regional zone.

There is no change in the diatom flora, but the dinoflagellate cysts on both sides of the lithological boundary at $38 \mathrm{~m}$ differ. Lingulodinium machaerophorum becomes relatively rare, whereas Operculodinium centrocarpum achieves higher frequencies, reaching its maximum abundance. The shift suggests that the influence of the open sea increased.

Foraminifers are common, their number increasing upwards. Their diversity is relatively high and increases upwards. Elphidium excavatum is no longer an important element. The fauna is a shallow-water assemblage. The major species are Ammonia parkinsoniana tepida, Elphidium margaritaceum, E. williamsoni, Nonion depressulum and $N$. germanicum. The assemblage

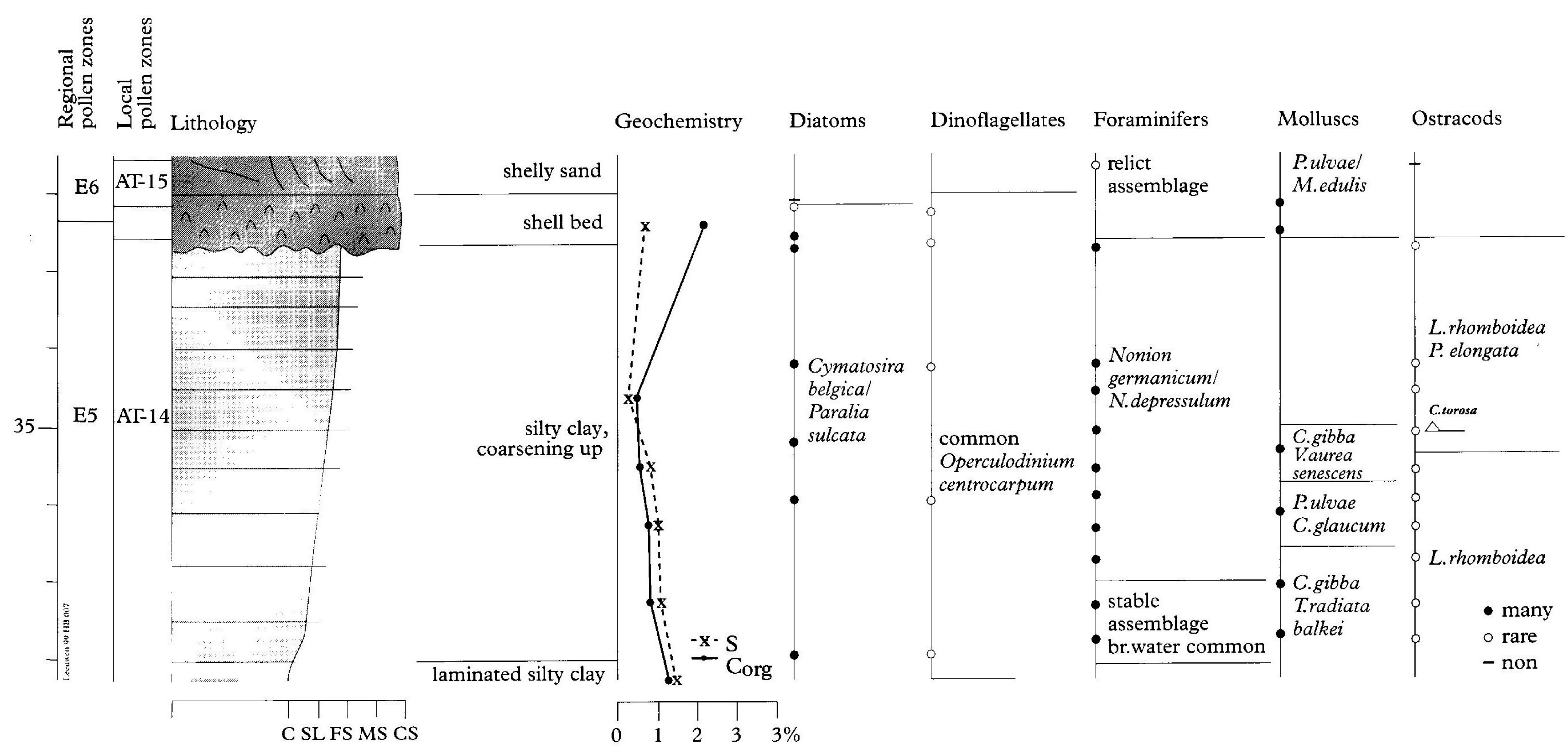

Fig. 7. Stratigraphy, lithology and characteristics of the 32-38 $\mathrm{m}$ below surface interval in the Amsterdam-Terminal borehole. Sample levels for the various analyses are indicated. 
strongly resembles that of the present-day Wadden Sea, and the abundance of $N$. depressulum indicates a subtidal environment.

Molluscs are common. Corbula predominates, except in one of the samples in the upper part of the interval in which both Peringia ulvae and Cerastoderma glaucum are abundant. The proportion of Corbula decreases upwards, indicating continued shallowing. The local abundance of Peringia and Cerastoderma indicates that lowered salinities prevailed. The percentages of Turboella decrease upwards; Zostera leaves are only found in the upper part of the interval.

Ostracods are fairly common and their assemblages tend to be more diverse than in the underlying sediments. The most important species are Loxoconcha rhomboidea and Pontocythere elongata. Both are considered to be autochthonous. P. elongata is restricted to the upper part of the unit. It is not an epiphyte but prefers sandy substrates. Most of the other species are highly transportable and probably allochthonous. This certainly holds for the non-marine Cyprideis toros $a$, which occurs in the upper part of the unit. All specimens are smooth, which suggests relatively highsalinity living conditions. In the Loxoconcha rhomboidea/Pontocythere elongata assemblage of the upper part of the interval, two species occur that are interesting from a climatic point of view, i.e., Aurila convexa and a single juvenile valve of Tenedocythere sp. Both species prefer water warmer than at present. The occurrence of Tenedocythere is of special interest, because this genus has never been described previously from the Eemian. In Europe, modern Tenedocythere is only known from the warm waters of the Mediter- ranean.

Shell bed (32.65-32.00 m) and shelly sand (32.00-28.10 m) (Fig. 8)

This unit consists of greenish-brown fine and medium sands containing shells. Mega-crossbedding is common. The base of the unit is a coarse and poorly sorted layer of shells, coarse sand, peat lumps and clay pebbles. The heavy-mineral assemblage is no longer dominated by hornblende and epidote, but has become a hornblende/alterite assemblage. The proportion of alterite increases upwards, and the volcanic minerals show the same trend.

The lowermost part of the unit (32.57-31.56 m) has yielded pollen spectra. They represent the uppermost part of local pollen zone AT-14 and AT-15. The boundary is correlatable with that between the Carpinus zone (regional zone E5) and the Picea zone (E6). The spectra from the shell bed are characterized by high percentages of Gramineae and Chenopodiaceae. The sand is represented by only one sample, and is characterized by a predominance of Cyperaceae pollen.

The U/Th age of the sediment at $29.86 \mathrm{~m}$ is 118.2 $\pm 6.3 \mathrm{ka}$.

The most diagnostic characteristic of this unit is the mollusc assemblage. The shell bed at the base is characterized by a high-diversity assemblage in which intertidal species such as Peringia ulvae, Mytilus edulis and Cerastoderma edule predominate. Subtidal species indicating an high-energy environment, such as $\mathrm{Lu}$ cinella divaricata, are also present. An assemblage overall similar to that above is found in the overlying

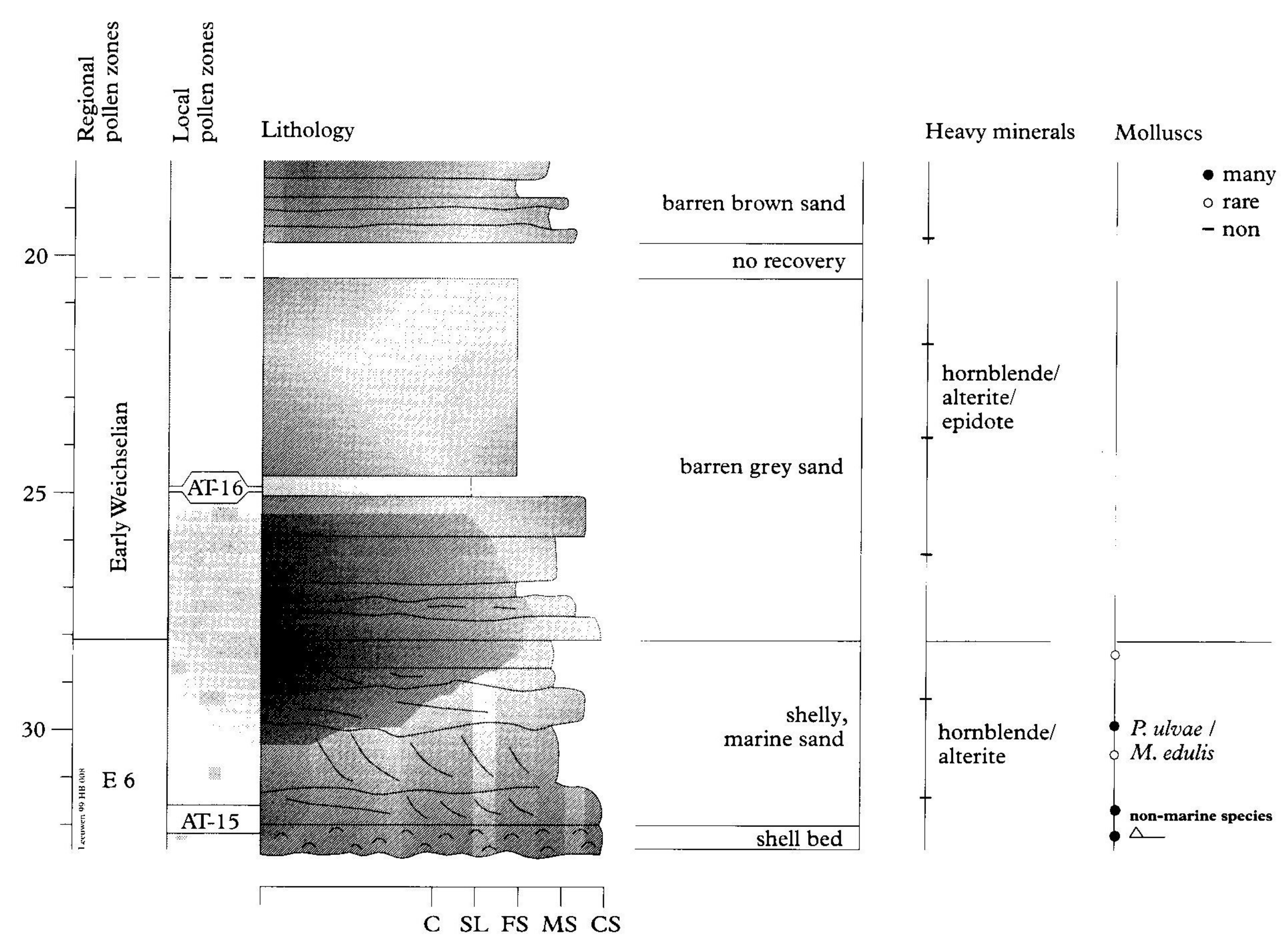

Fig. 8. Stratigraphy, lithology and characteristics of the $18-32 \mathrm{~m}$ below surface interval in the Amsterdam-Terminal borehole. Sample levels for the various analyses are indicated. 
sands, but the number of specimens is much lower. Non-marine species such as Trichia hispida, Planorbis planorbis and Pisidium henslowanum occur throughout the interval. Their presence shows that fresh water was supplied to the basin.

The interval was not systematically studied for other groups. The shell bed contains a Cymatosira belgicadominated diatom assemblage with abundant Nitzschia navicularis, a species characteristic of mudflats and salt-marshes, at one level. Dinoflagellate cysts are very scarce, the assemblage comprising Spiniferites spp. and Operculodinium centrocarpum. The sands contain a very poor foraminiferal assemblage characterized by abundant Ammonia parkinsoniana tepida. This assemblage is probably a relict fauna (cf. Uffenorde, 1982).

\section{Weichselian and Holocene sediments}

The top part of the section, with Weichselian and Holocene deposits, has been subdivided into only two sediment units: sand and overlying deposits.

\section{Sand $(28.10-20.45 \mathrm{~m})$}

The shell-bearing sands are overlain by barren greyish and greenish-brown fine and medium sands, with a clayey interval between 24.95 and $24.60 \mathrm{~m}$. High- and low-angle cross-lamination is present in the sands. Some reworked shell fragments occur at the base of the sands. The heavy-mineral content is characterized by high proportions of hornblende, alterite and epidote.

The clayey interval yields pollen spectra that are characterized by the abundance of non-arboreal pollen and relatively high percentages of Hippophae and funiperus (local pollen zone AT-16). The assemblage is interpreted as indicating a cold climate, and the interval is therefore assigned to the Early Weichselian. An Eemian age cannot be completely excluded, however, because the spectrum could represent dune vegetation under an interglacial climate.

\section{Overlying deposits}

The uppermost twenty metres consist of peri-fluvioglacial and aeolian silty, very fine sands with a thin gyttja layer intercalated and overlain by a marine clay and landfill immediately below the modern ground surface. The gyttja and the silty sands yield pleniglacial pollen spectra. The boundary between the Weichselian and Holocene deposits is at $13.85 \mathrm{~m}$.

\section{Palaeomagnetism}

Intensities of natural remanent magnetisation (at 25 $\mathrm{mT}$ ) in the $31-76 \mathrm{~m}$ interval generally vary between 0.4 and $1.0 \mathrm{~mA} \cdot \mathrm{m}^{-1}$, but significantly higher values occur in the uppermost part of the Eemian sediments $(32-37 \mathrm{~m})$, in the Saalian/Eemian boundary interval $(60-65 \mathrm{~m})$ and particularly in the Saalian varved clays, below approximately $75 \mathrm{~m}$ (Fig. 9).

The low field magnetic susceptibility, $\chi$, shows typical values of $50-100 \cdot 10^{-6}$ SI. Higher than average susceptibilities are found in the Saalian deposits, with very high values below $75 \mathrm{~m}$ in the lowermost unit of
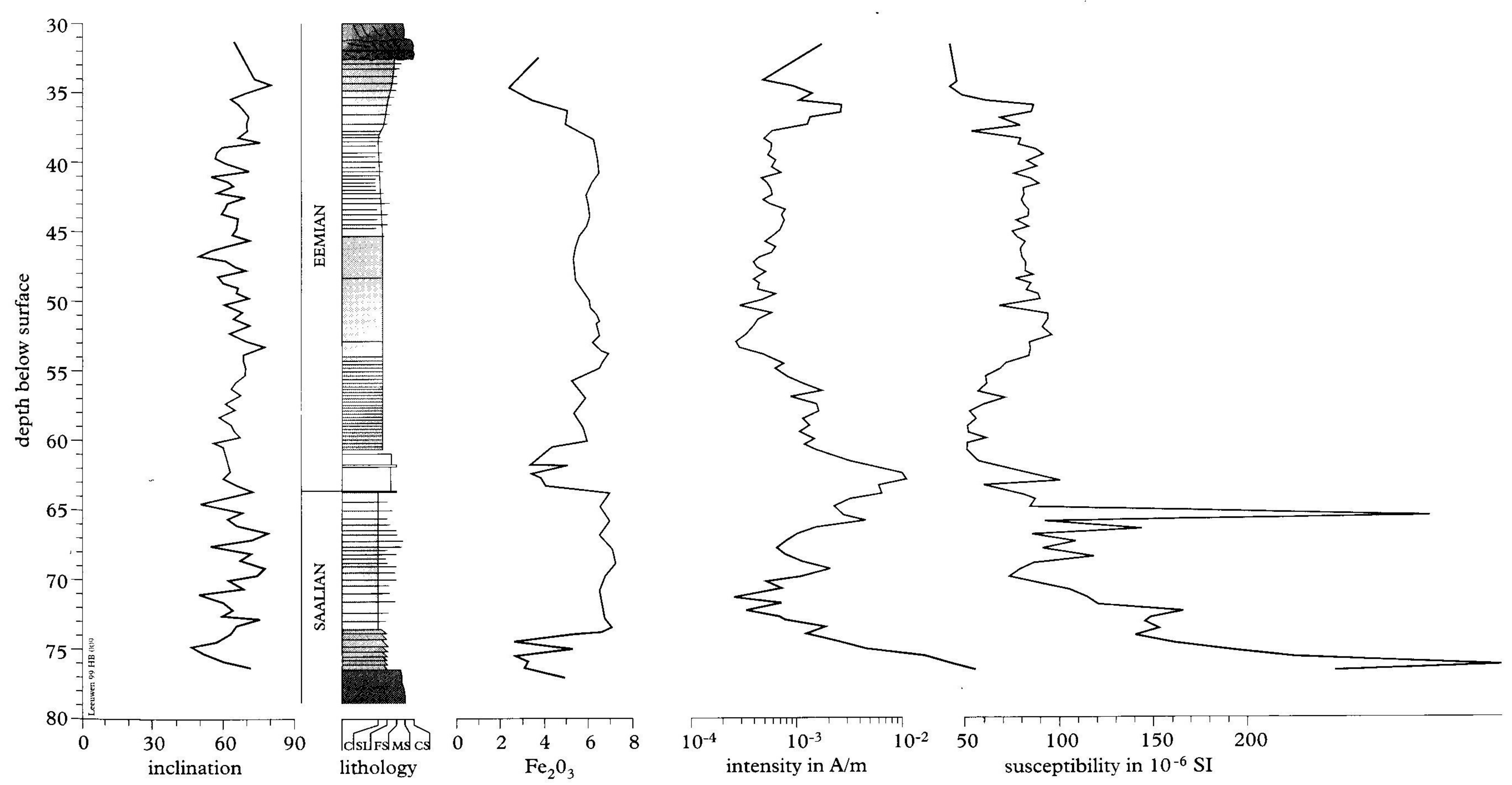

Fig. 9. Inclination, intensity and susceptibility of natural remanent magnetisation in the Eemian - Saalian interval (31-76 $\mathrm{m}$ below surface) in the Amsterdam-Terminal borehole. The iron content, as determined by XRF analysis, and the lithological column are shown. 
varved clays. Except in the interval below $75 \mathrm{~m}$, no positive correlation has been found between susceptibility and intensity. An inverse relation was actually seen in the Eemian sediments between 62 and $38 \mathrm{~m}$. This lack of a positive correlation suggests that $\chi$ is determined by paramagnetic clay minerals rather than by ferrimagnetic carriers of remanence. Evidence in support of this suggestion can be derived from an overall relation between $\chi, \mathrm{Fe}_{2} \mathrm{O}_{3}$ (Fig. 9) and grain size (not shown). Low values of $\chi$ tend to correspond to a low percentage of $\mathrm{Fe}_{2} \mathrm{O}_{3}$ and a low proportion of clay, again with the exception of the interval below $75 \mathrm{~m}$.

Anisotropy of the magnetic susceptibility shows a typical sedimentary fabric. The maximum axes of susceptibility $\left(\mathrm{k}_{\max }\right)$, measured after aligning the declinations to the North, appear to be distributed randomly in the horizontal plane, which indicates deposition in a low-energy environment.

\section{The Blake reversal excursion}

All characteristic remanent magnetisation (ChRM) directions, derived from demagnetisation using alternating fields, are of normal polarity. Some of the specimens in the $70-75 \mathrm{~m}$ interval seem to pass the origin, but a clearly reversed component is never present. Moreover, at high fields ( $>50 \mathrm{mT}$ ), many of the samples display spurious magnetisations, which mask the direction of the natural remanent magnetisation. These spurious magnetisations are caused by the acquisition at high fields of a giro-remanent magnetisation (Dankers \& Zijderveld, 1981), which may be related to the occurrence of magnetic Fe sulphides. All data considered, it must be concluded that there is no reliable indication of reversed polarity and hence no indication of the Blake reversal excursion.

Age estimates for the Blake event vary between 120 and $100 \mathrm{kA}$ (Nowaczyk et al., 1994; Langereis et al., 1997 , and references therein). This variation probably arises from delayed acquisition of remanent magnetisation for which various mechanisms, all strongly dependent on sedimentary environment, are responsible (Van Hoof \& Langereis, 1991). This delayed acquisition of remanence may cause a reversal to seem older, but never younger. Hence, the stratigraphically youngest intervals are taken as providing the most reliable age estimates.

There are several records of the Blake event in an interval post-dating MIS 5.5 (5e), for instance in the loess sequence of the Tönchesberg (Germany). The event was found there in loess overlying an Eemianage palaeosol (Reinders \& Hambach, 1995).

Theoretically, the absence of reversed polarity in sediments in the Amsterdam-Terminal borehole could be attributed to early diagenetic processes (cf. Langereis et al., 1997). It is considered, however, that the NRM is of primary origin, which suggests that delayed acquisition did not occur in the Eemian sediments. This confirms that the Blake excursion is a relatively young event.

\section{Depositional history}

\section{Saalian deglaciation}

The poorly sorted, heterogeneous sands at the base of the borehole represent a facies that is widespread in the deepest parts of the Amsterdam basin; glacial diamicton is found only locally on the basin floor (De Gans et al., 1987). The composition of the sediment suggests that it is a mixture of material transported over a long distance by the glacier with that from more local sources. The sands are thought to represent a first melting product of the glacier, and is probably a pro- or subglacial facies.

The varved sediments above the sands were deposited in a meltwater lake (Fig. 10a). The lower interval with the low organic-matter content resembles a facies described by Jelgersma \& Breeuwer (1975), who suggested that the decreasing thickness of the varves reflects progressive glacial retreat.

Essentially the present authors agree with this interpretation, but we picture the ice mass as a large dead-ice field instead of a retreating glacier. The lamination of the sediment suggests that there was little biological activity in the bottom. The evidence from Amsterdam-Terminal shows that the organic-carbon content is low by all standards, which indicates that shortage of food rather than lack of oxygen was responsible for the low level of biological activity at the time. As a consequence, it is assumed that the productivity of the lake was low.

Productivity increased dramatically during deposition of the upper part of the varved unit. This is not only indicated by the organic-carbon content, which is higher by an order of magnitude, but also by the much higher percentages of carbonate and sulphur. The carbonate is considered to be authigenic. It formed when primary producers extracted so much carbon dioxide from the water that the lake became supersaturated with respect to carbonate. The sulphur is probably mainly a product of the degradation of organic matter by sulphate-reducing bacteria. The high sulphur content, both absolutely and relative to carbon, is exceptional in a fresh-water environment and suggests that the sulphate concentration in the water was high.

The sharp rise of productivity can be explained in 

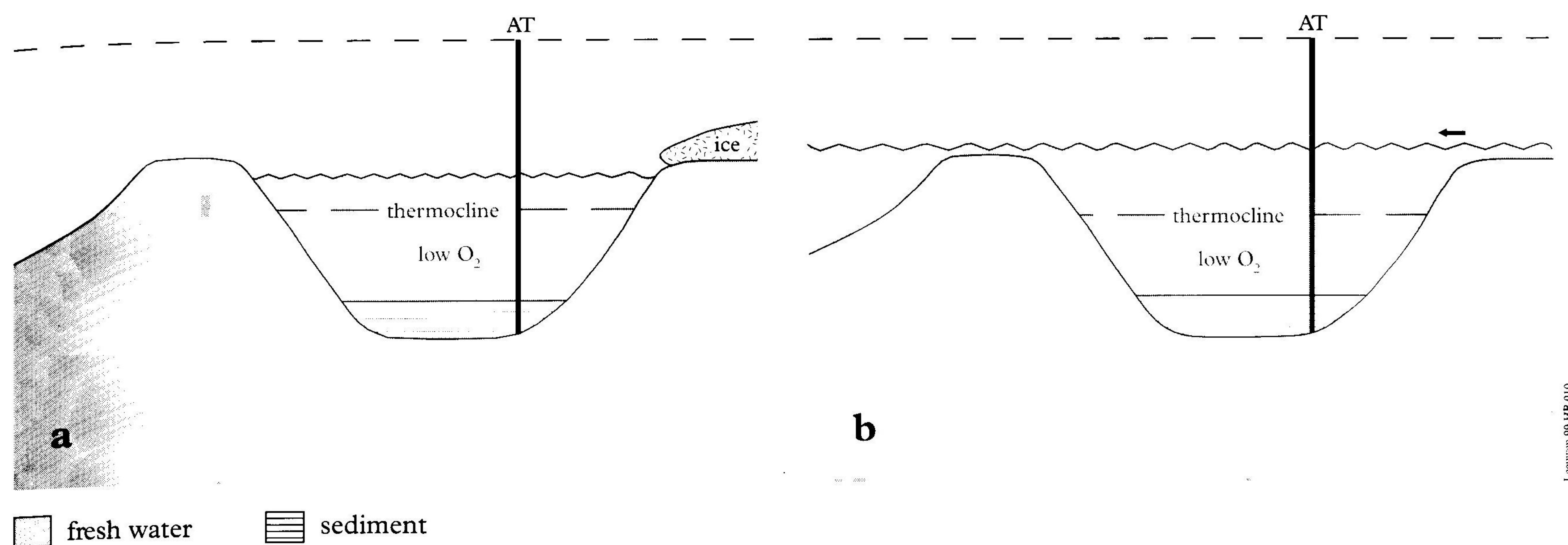

Fig. 10. The Amsterdam basin during deposition of (a) the late Saalian varved clay, and (b) the main part of the late Saalian lacustrine clay. The main direction of water supply, the site of the Amsterdam-Terminal borehole and the present-day surface are indicated. West is on the left-hand side.

several ways. The most obvious way is by an increasing input rate of nutrients. Such a scenario would imply a change in source and thus in drainage pattern: the lake was no longer fed by the melting ice mass alone, but nutrients were brought in also from other sources. An alternative is that not lack of nutrients but lack of light was responsible for the initially low productivity of the lake, for instance, because a large part of the lake remained to be ice-covered. Under these conditions, a nutrient reservoir gradually built up that could be tapped as soon as the lake became ice-free. We favour this latter option. The bulk of the nutrients was probably derived from the ice mass and its sediment load. As the water contained abundant sulphate, it is thought that much of the sediment carried by the glacier was of marine origin.

In view of the high productivity, the lamination of the sediment can no longer be linked to a low organic-matter flux. Oxygen levels at the bottom of the lake must have been low. These low concentrations could be attributed entirely to a large flux of organic matter, but it would certainly have helped to allow a stratification to develop when the lake was deep enough.

The thick interval of lacustrine clay that overlies the varved unit is the main Saalian-age facies in the Amsterdam basin (Jelgersma \& Breeuwer, 1975; De Gans et al., 1987). The organic-carbon, sulphur and carbonate contents suddenly decrease at the base of the interval, which shows that the level of productivity - though definitely higher than during the deposition of the lower varved interval - dropped significantly. Again there is no need to invoke a change in nutrient supply. It is thought that the lower productivity simply implies that a dynamic equilibrium with respect to nutrients was reached. After an intitial stage of nutrient excess, input and output of nutrients achieved a balance. The grad- ual disappearance of lamination in the sediment suggests higher oxygen levels at the bottom, which may well be the direct result of lowered productivity.

The clay content, which typically varies between $55 \%$ and $70 \%$ (dry weight), is much higher than in the varved interval (15-30\%) and suggests a more distant sediment source. The pollen record shows higher and upwards increasing frequencies of Pinus which, considering the buoyancy of the grains, does not conflict with this view. The intercalated sand layers have probably a different and more local origin. Their heavy-mineral content indicates that they may be derived from the fringes of the basin. All things considered, one is tempted to interpret the clays as deposited in a lake fed by a gradually shrinking ice mass. De Gans et al. (2000 - this issue), however, make a strong case for deposition in a lake that was no longer fed by a melting ice mass. They argue on the basis of regional geological evidence that the clays accumulated after the ice had disappeared. By this time, the Amsterdam basin had become part of a large, deep lake that was fed by the main branch of the Rhine (Fig. 10b). The lake level was estimated at $25-30 \mathrm{~m}$ below NAP. This hypothesis is accepted here. Since the scenario implies a change in source, the interpretation of the pollen record as consisting of merely reworked grains can only be questioned. The high proportion of Pinus pollen could record the contemporaneous existence of pine forests far beyond the area around the lake.

\section{End of the Saalian}

Conditions must have changed significantly during deposition of the uppermost part of the Saalian clay, both around and in the lake. The relatively high proportion of vermiculite suggests that soils had begun to 


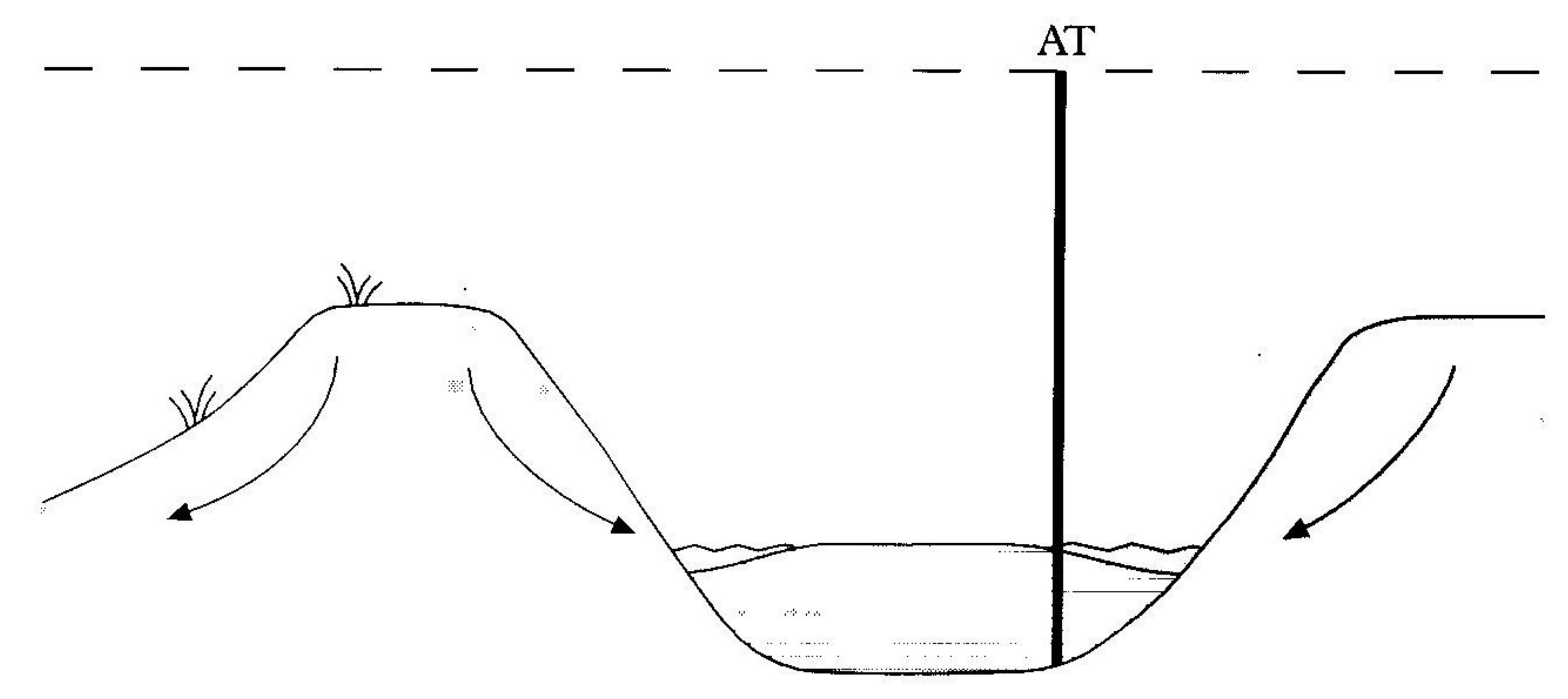

$\mathbf{a}$

fresh water

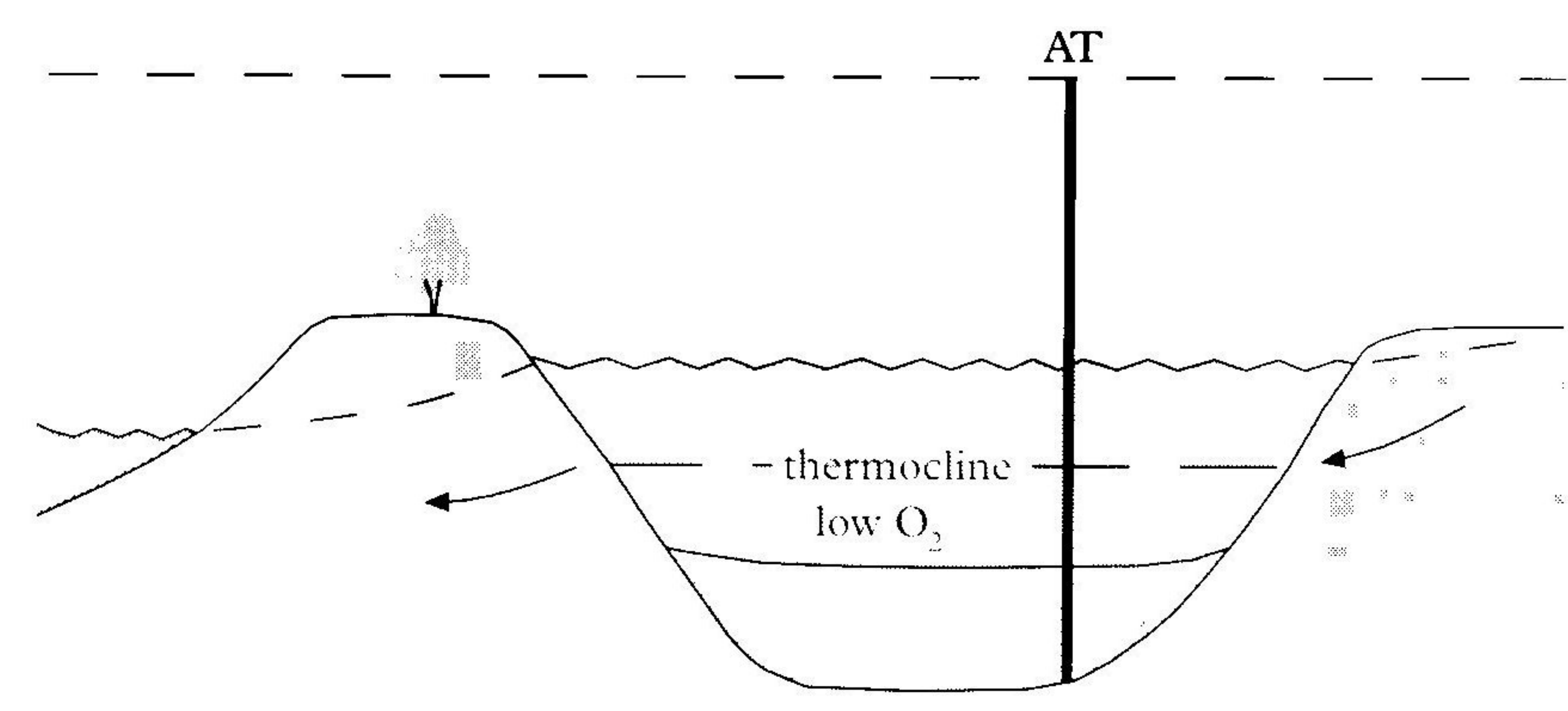

b

Fig. 11. The Amsterdam basin during deposition of (a) the uppermost part of the late Saalian lacustrine clay, and (b) the early Eemian lightcoloured diatomite (regional pollen zones E1-E3). Groundwater flow, the site of the Amsterdam-Terminal borehole and the present-day surface are indicated. West is on the left-hand side.

develop. The pollen record confirms this interpretation, since it shows that the area surrounding the lake became colonised by higher plants. The landscape changed into a tundra with patches of juniper.

The changes in the vicinity of the Amsterdam-Terminal site were followed by changes at the site itself, as diatoms appeared in the late Saalian sediments. Their presence shows that biogenic opal could be preserved in the bottom, which implies a change in water chemistry. There may well be a causal link with the changes around the site, because development of soils implies intensified weathering, which would have resulted in a larger flux of silica.

More importantly, the composition of the diatom assemblage suggests that the term 'lake' was no longer appropriate to describe the depositional environment. The presence of Navicula jaernefeltii is indicative of very shallow water. The remains of the species are considered to be in situ because the fragility of their frustules seems to preclude transport. Thus it is assumed that the lake was reduced to a shallow pool at the time (Fig. 11a).

The mechanism thought to be responsible for the reduction in the lake is given by De Gans et al. (2000 - this issue). They argue that the lake, of which the Amsterdam basin formed part, drained because its westernmost sill was eroded. The Vecht valley, a deeply incised valley to the North of the Amsterdam basin, formed and became the main channel of the Rhine. The Amsterdam basin was thus cut off from the supply of river water and consequently the lake became smaller fragmented. The occurrence of the moss, $\mathrm{Am}$ blystegium riparium, which predates the appearance of $N$. jaernefeltii, probably records a rather early stage in the fragmentation of the lake. Its occurrence shows that the area around the site became dry land. mained in the Amsterdam basin. It is therefore remarkable that sediment accumulated at the Amsterdam-Terminal site. The sediment is thought to have been washed in - possibly also blown in - from local sources. The sandy layers that are intercalated in the clay have a different heavy-mineral composition than the sandy layers deposited before the lake fragmented. The difference suggests that the sands in the immediate vicinity of the Amsterdam-Terminal site had a different composition than the sands in the surroundings of the former lake. The sandy layer that forms the top of the Saalian contains some gravel, which supports the interpreted very local origin of the coarse sediments.

The disappearance of the lake corresponds with earlier observations. For example, Zagwijn (1983) attributed decalcification of the uppermost Saalian sediments at topographically higher sites in the Amsterdam basin to emersion. Visual inspection of the Amsterdam-Terminal cores gives no reason to believe that the site actually emersed, nor do the results of geochemical analysis. In comparison to the Eemian record, however, the Saalian sequence has a low water content. The clay commonly contains close to $20 \%$ of water, which is much lower than the $50 \%$ that is typical of the Eemian clays. The contrast suggests that the Saalian sediments were dehydrated before the beginning of the Eemian. In view of the low-lying position of the site, it is considered unlikely that the groundwater table fell to a level below the base of the borehole. It is more probable that freezing led to an irreversible loss of water. Tundra-like conditions prevailed and disappearance of the lake probably allowed permafrost to develop in the substrate.

Eventually only isolated, sediment-starved pools re- 


\section{Beginning of the Eemian stage}

The lower boundary of the Eemian is placed at the base of the light-coloured diatomite and coincides with the base of regional pollen zone E1 at $63.5 \mathrm{~m} \mathrm{(-}$ $62.05 \mathrm{~m} \mathrm{NAP}$ ). Conceptually, it marks the arrival of the treeline, i.e., the change from a tundra-like environment into a Betula-dominated wooded landscape.

The change in vegetation was accompanied by a change in depositional environment. In contrast to the uppermost Saalian clay, the light-coloured diatomite is formed in a lake proper (Fig. 11b). The biogenic character of the sediment shows that the input of clastics was negligible, which implies that the lake was isolated and fed by seepage. Following the same line of reasoning as for the Saalian varved interval, the lamination and the low carbon content of the diatomite suggest that lake productivity was low.

The composition of the diatom flora confirms this view. The diatom record also provides information about the depth of the lake. The flora consists almost entirely of planktic species. The virtual absence of benthic and epiphytic species suggests that the bottom of the lake was below the photic zone. There are no indications that the turbidity of the water was high. On the contrary, both the low productivity and the absence of clastic input suggest that light could penetrate deeply into the water. As a consequence, the lake must have been fairly deep, which means in excess of ten metres. Considering the excellent preservation of the diatom frustules, which shows that the bottom water was close to saturation with respect to opal, it is thought that the lake was sufficiently deep to allow the development of stratification during summer.

The change from a shallow pool into a lake could have been controlled by climate alone. A higher groundwater table could easily be attributed to a positive shift in the precipitation/evaporation balance. Because the early Eemian was a period of a rapid marine transgression, it is thought likely, however, that the change was to a large extent controlled by a rising sea level.

The low productivity during early Eemian times suggests that seepage water maintained a low flux of nitrate and phosphate. By contrast, the input of silica must have been high, at least relatively. The explanation may be found in a combination of factors. Firstly, purely siliceous sediments were present in abundance. The substrate in and around the glacial basins was composed mainly of coarse-grained clastics (Van den Berg \& Beets, 1987). Quartz-rich sands of the Enschede Formation predominate in the subsurface of the Amsterdam basin (Burger, pers. comm.). Secondly, the beginning of the interglacial was a period during which a large biomass was established on land, as the poor shrub and herb vegetation was replaced by forests. This vegetation depended to a large extent on nutrients made available locally by bacterial activity and weathering. The phospate and nitrate supply was presumably entirely consumed to build up the biomass. Silica, on the other hand, was probably produced in excess, because plants - excluding grasses generally have a low silica demand. As a consequence, relatively large amounts of silica could be exported by the groundwater.

\section{Hiatus}

The change in the diatom flora across the Saalian/ Eemian boundary appears to be abrupt, and the same holds for the pollen record. Sediments formed in a deep, interglacial lake lie directly op top of sediments formed in a shallow, glacial pool. There is no record of the occurrence of a shallow stage in the interglacial lake record, which suggests discontinuity.

It seems probable, indeed, that the boundary represents a sedimentary hiatus. A new steady state with respect to silica had to be reached, because the volume of water in the basin had increased significantly. Moreover, it must have taken some time before the silica concentration built up to saturation level. This time-span is not represented in the sediments because there was hardly any clastic input, nor was there sufficient silica in the bottom water to preserve a substantial part of the diatom rain.

\section{Transitional interval}

According to the time-scale used by Zagwijn (1996), the light-coloured diatomite represents an interval of 500-1000 years. The diatom assemblages from this period show little change, which suggests that, at least as far as the upper water layers are concerned, the environment remained fairly stable.

The phase of stability came to an end during deposition of the uppermost part of the light-coloured diatomite, which began during the Quercus phase (regional zone E3). In the top of the light-coloured diatomite and the overlying Harting layer, changes in flora and fauna rapidly follow each other. Dinoflagellate cysts, marine diatoms, foraminifers and molluscs successively appear and finally the diatoms change from a predominantly fresh-water assemblage into a brackish-water assemblage. The succession clearly shows a steadily increasing influence of the sea, which is no doubt controlled by the rising sea level. During these changing conditions, the lake gradually developed into a restricted marine environment for which the term 'lagoon' seems most appropriate. Before dis- 
cussing its depositional history in detail, it should be emphasized that the lagoonal character of the environment can be interpreted from the physiography of the basin. Since the disappearance of the ice mass, the topography of the glacial landscape had changed only a little: sills in the West and North-West inhibited the exchange between the Amsterdam basin and the open sea during the Eemian (De Gans et al., 1987).

\section{First stage}

The interval representing the first stage in the development of the lagoon includes the uppermost part of the light-coloured diatomite and the lower part of the Harting layer, i.e., the part characterized by a freshwater Fragilaria-dominated diatom flora. The first marine organisms to arrive were dinoflagellates of the genus Brigantedinium. Their appearance marks the moment that the sea level had risen to the depth of the sill. Since dinoflagellate cysts are not continuously present in the sediments from the late Quercus phase, the sea probably only occasionally overtopped the sill. The diatoms show that the surface-water salinity was not significantly influenced by the incoming seawater. Either the amount of salt water was too low or the denser salt water made its way directly into the deep parts of the basin. In the latter case, a pronounced salinity stratification might have developed. In any case, the low carbon content of the sediment indicates that the salt-water input did not significantly change the productivity in the basin.

The sediments from this first phase are characterized by a relatively high sand content and contain poor assemblages of marine molluscs and foraminifers. It seems unlikely that the benthic marine organisms actually lived at the bottom of the lagoon. Because the assemblages are clearly of mixed composition, it is thought that the benthic fossils, as well as the sands, were washed in.

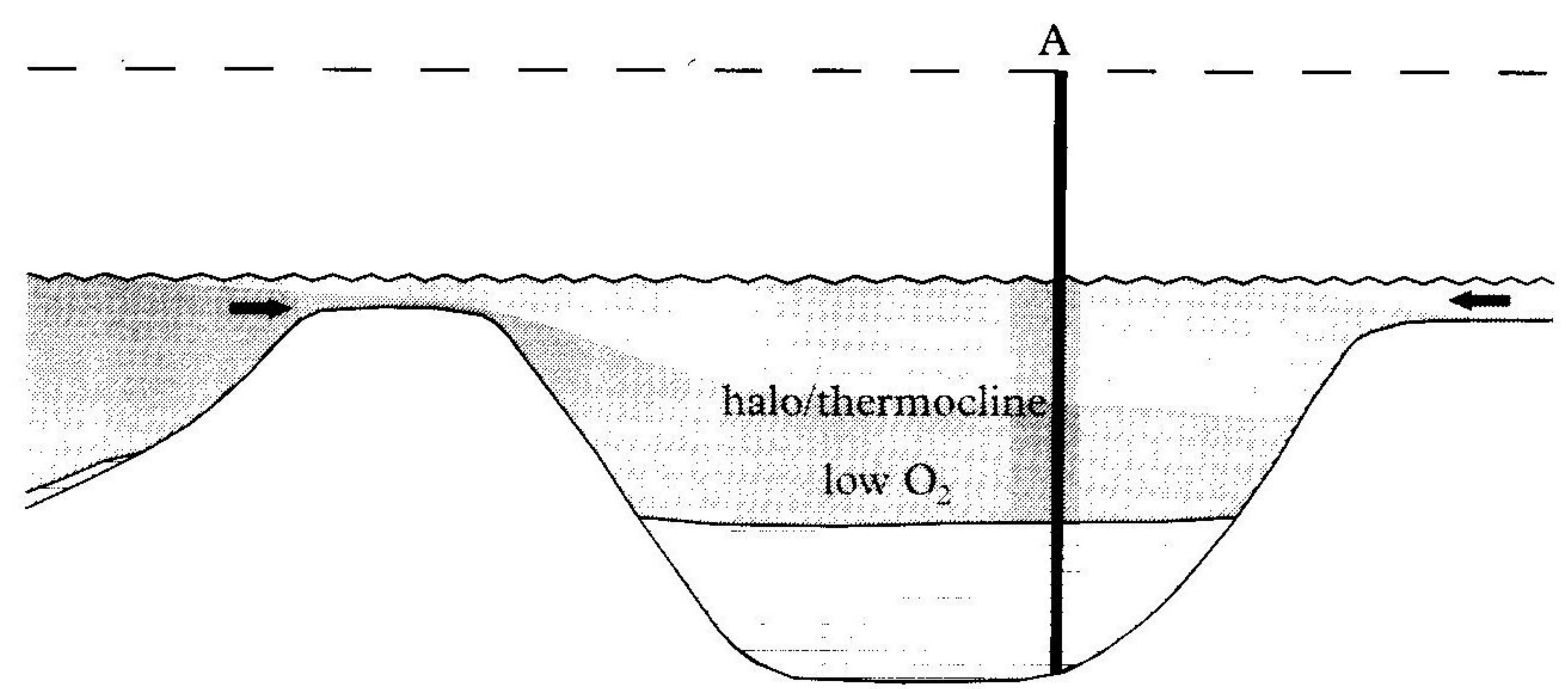

$\mathbf{a}$

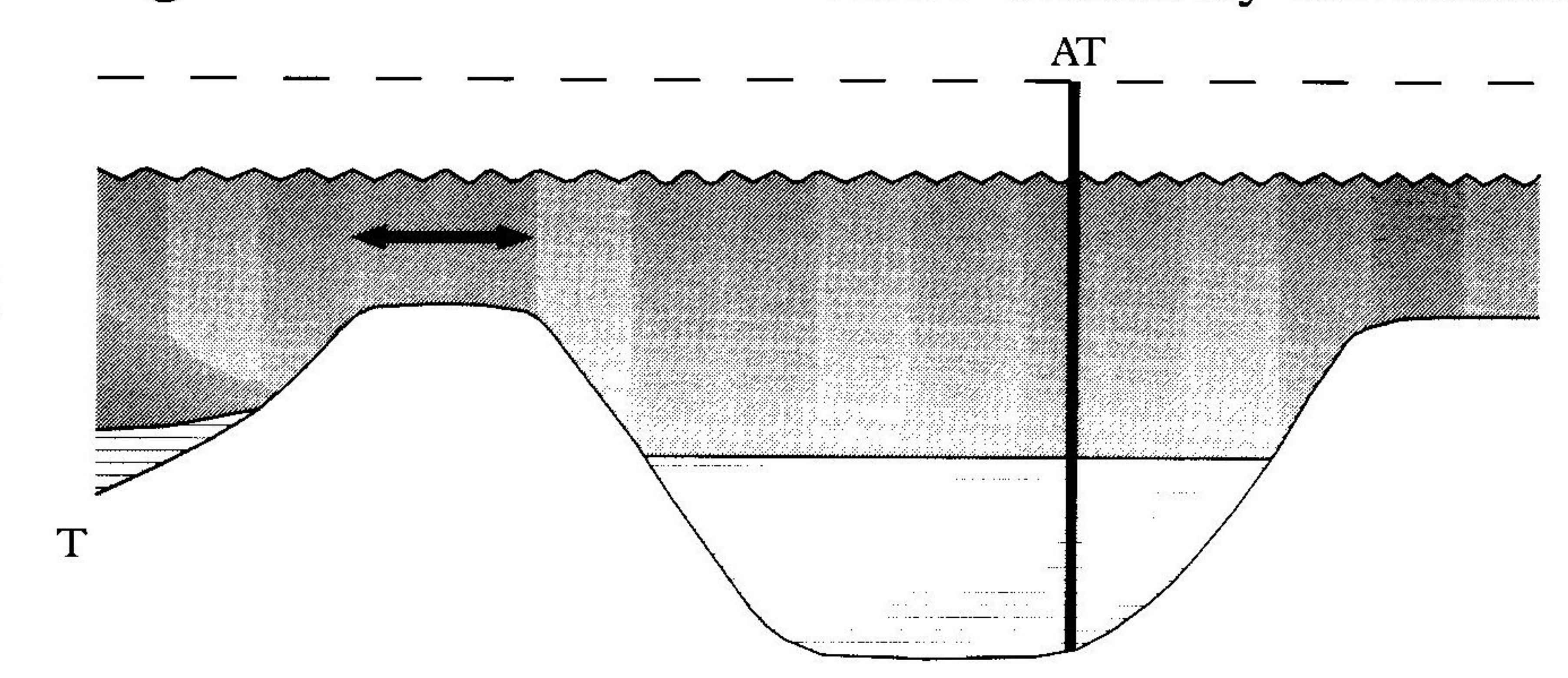

b

\section{Second phase}

The second step in the development of the lagoon is represented by the upper part of the Harting layer, which is characterized by very high organic-carbon levels. At $61.55 \mathrm{~m}$ depth, brackish-water diatoms become predominant and gradually a brackish dinoflagellate flora also develops. By this time, practically at the beginning of the Corylus phase (regional zone E4a), the site was permanently influenced by the sea. The exchange of water across the sill must have increased to the extent that the surface layer was no longer fresh water.

The lagoonal bottom waters must have had a relatively high salinity, yet life conditions were unfavourable for benthic marine organisms. Molluscs are not present and the foraminiferal faunas are very poor and composed of shallow-water, brackish elements that might well be allochthonous. Lack of food can no longer account for the low level of benthic life, because the high organic-matter content of the sediment shows that the basin had become a sink of organic carbon. Instead, it seems likely that the oxygen levels at the bottom were low. The oxygen deficiency is attributed to a combination of factors. Firstly, productivity in the lagoon increased significantly in response to the input of nutrients from the sea. Secondly, the influx of salt waters probably favoured stratification of the water column.

\section{A stratified lagoon}

The Harting layer is overlain by a laminated silty clay. The lithological boundary marks a drastic change in sedimentary regime. Under the influence of a continuously rising sea level, the exchange with the open sea steadily intensified (Fig. 12a). Significant amounts of suspended matter were brought into the lagoon together with the marine waters effectively terminating

Fig. 12. The Amsterdam basin during deposition of (a) the Eemian lower laminated clay (regional pollen zones E4a-E4b), and (b) the Eemian crumbly clay (regional pollen zones E4b-early E5). The main direction of water supply, the site of the Amsterdam-Terminal borehole and the present-day surface are indicated. West is on the left-hand side. 
a long interval of biogenic sedimentation. The change took place relatively early during the Corylus phase (regional zone E4a).

The intensification of the exchange with the open sea had a distinct effect on the bottom environment. Foraminifers are much more abundant already at the base of the laminated clay than in the Harting layer, which shows that the lagoon became better ventilated. The molluscs respond in a similar way and, moreover, their number significantly increases towards the top of the interval, showing that living conditions continued to improve. Yet, as the laminated character of the sediment and the high content of organic matter indicate that the oxygen level at the bottom remained low, it must be concluded that the lagoon remained stratified to some extent.

Changes in the foraminiferal faunal composition support this conclusion. Assemblages from above and below the thermocline alternate, which suggests the presence of fairly stable stratification. Because the fauna from above the thermocline had a distinct brackish-water character, it appears that the stratification was determined by a temperature as well as a salinity contrast.

The increased influence of the open sea seems to have affected the planktic ecosystem in a more gradual way. Disregarding the remarkable peak of Thalassiosira nordenskioeldii directly above the boundary, the diatom assemblages at either side of the lithological boundary are very similar, and the same holds for the dinoflagellate cysts. Within the laminated clay, however, a number of changes are observed that show that the salinity increased steadily, i.e., the incoming of spores of the diatom Stephanopyxis turris, their subsequent disappearance and the changing morphology of the dinoflagellate cyst, Lingulodinium machaerophorum. Among the diatoms, a Hyalodiscus scoticus/Grammatophora oceanica assemblage was gradually replaced by a Cocconeis disculoides assemblage. While both assemblages indicate brackish-water, this shift may also be due to an increasing exchange with the open sea. Because the Cocconeis disculoides assemblage has its modern analogue in the western Baltic, its presence implies an environment of a large stratified, hyposaline lagoon, with a low tidal range and low turbidity.

\section{Cold waters}

At this point, it is important to consider the occurrence of the high-latitude diatom, Thalassiosira nordenskioeldii. Its peak presence in the lowermost part of the laminated clay coincides with the peak occurrence of the foraminifer, Buccella frigida, which likewise favours low water temperatures. Both species are present throughout the laminated clay, showing highly variable abundances. The resemblance of the abundance patterns is too great to be accidental and suggests a common cause. It is accepted that both species indicate low temperatures, indeed. On the other hand, the general opinion that water temperatures in the Eemian were higher than in the Holocene is accepted - indeed both the dinoflagellate cysts and the ostracods in the present study provide evidence that corroborates such a temperature difference. To explain the paradox, a periodically pronounced seasonal contrast in water temperature is thought to have occurred, with winter temperatures much lower than under the present-day climatic regime. The levels at which the high-latitude species abound record periodically exceptionally cold winters, during which very cold, saline water penetrated the lagoon. Thalassiosira nordenskioeldii is a species of the open sea. Its exceptional abundance can only be understood if it actually flourished in the lagoon, implying that cold waters were at - or close to - the surface until at least the spring bloom. The lagoon water must, in this case, have been relatively well mixed during winter. By contrast, the presence of cold water favoured the development of a steep thermocline during summer and thus of a pronounced stratification.

Changes in the assemblages of foraminifers and molluscs further suggest that the lagoon deepened during deposition of the laminated clay. Sedimentation was apparently unable to keep pace with the rising sea level. It is difficult to ascertain the actual depth of the lagoon. A mollusc, Turboella radiata balkei, which is relatively abundant except at the top of the interval, is assumed to have lived on eelgrass (Zostera). These plants normally grow down in western Europe to a depth of about $10 \mathrm{~m}$, but a lower depth limit of $40 \mathrm{~m}$ has been reported from California (Rasmussen, 1973). It can certainly not be excluded that $T$. radiata balkei had been transported. The figure of $10 \mathrm{~m}$ provides only a minimum depth. As a fairly stable stratification was present during most of the time, a depth of several tens of metres is thought to be a fair estimate.

\section{Well mixed waters}

The deposition of the peculiar, crumbly clay, which began in the middle of the Corylus/Taxus phase (regional zone $\mathrm{E} 4 \mathrm{~b}$ ), marks a rather fundamental change in the evolution of the Amsterdam basin. For the first time during the Eemian, homogeneous sediments were formed, which shows that the ventilation of the lagoon improved, making the deeper parts a more hospitable environment for benthic life (Fig. 12b). As a consequence, less organic matter was preserved in 
the sediment, which accounts for the lower organiccarbon and sulphur content as well as for the absence of Zostera leaves. Moreover, while living conditions must have improved in general, the niche occupied by the scavenging mollusc, Hinia pygmaea, was completely destroyed. The improved ventilation was probably accompanied by a further weakening of the salinity stratification. Brackish-water indicating species had become subordinate among all groups of organisms, which suggests that a relatively well mixed lagoon developed.

This development was actually a rather predictable step in the evolution of a basin so strongly controlled by a rising sea level. It demonstrates that the sea level had risen to such a height that the sill became insignificant as a barrier. Free exchange between open sea and lagoon led to an intensification of circulation. It also seems that the tidal influence increased. Higher percentages of Chenopodiaceae among the pollen, as well as the appearance of the diatom species, Nitzschia navicularis, indicate that marshes began to develop around the lagoon. The intensification of the water circulation led to the basin losing much of the peculiarities that had characterized it up to this time. The severe dissolution of diatoms in the crumbly clay shows that the basin was no longer a sink for biogenic opal. In addition, the disappearance of the species indicating cold water, among both diatoms and foraminifers, probably reflects that cold waters could no longer be isolated in the lagoon.

It must nevertheless be emphasized that the environment was still lagoonal, as shown by the bulk of the palaeontological data. Among the benthics, muddwelling, open-marine foraminifers, such as Virgulina, Bulimina or Cassidulina, are completely absent and the same applies to the mollusc, Turritella. The assemblages of dinoflagellate cysts retain their overall lagoonal aspect, with high abundances of species such as Lingulodinium machaerophorum and Diplopelta symmetrica. The diatom signal is, however, somewhat aberrant, because it essentially concerns an open-sea assemblage much like that found in modern North Sea sediments. Planktic species are typically absent. Their absence is probably the result of dissolution. In contrast to the dissolution effect, already mentioned, the opal is thought to have dissolved in the water column rather than at the bottom. As a consequence, the diatom record fails to provide information on surfacewater conditions here.

The benthic organisms seem to provide information concerning the depth of deposition. The common occurrence of the molluscs Nucula sp. and Hyala vitrea suggests that the crumbly clay was deposited at an even greater water depth than the underlying lami- nated clay. On the other hand, the appearance at the same level of significant numbers of the foraminifer, Ammonia parkinsoniana s.l., would generally be considered an indication of a shallowing environment. The present authors think that neither of the changes can be interpreted in terms of depth. The three species suddenly appeared and immediately reached fairly high frequencies. This suggests that they primarily responded to the increased oxygen levels in the bottom water. The persistent absence of epiphytic molluscs such as Turboella radiata balkei seems a more reliable indicator of water depth, because it shows that Zostera meadows did not occur in the vicinity of the site, which again confirms a further deepening of the lagoon.

In spite of the fact that the environment can be reconstructed in great detail, a plausible explanation for the crumbly appearance of the clay is not obvious. The sediment appears to have been broken up and it is tempting to think of a syneresis effect, but this process cannot be related to the environmental setting reconstructed herein.

The sedimentary succession suggests that the crumbly clay represents a phase of exceptionally unobstructed exchange between the lagoon and the open sea. This phase ended shortly after the beginning of the Carpinus phase (regional zone E5). The crumbly clay is overlain by a normal, homogeneous clay and the changes that accompany the lithological transition indicate a return to more lagoonal conditions. Zostera leaves have once again been preserved, the sulphur content of the sediment increased and the scavenging mollusc, Hinia pygmaea, returned. The frequencies of the open-marine dinoflagellate cyst, Operculodinium centrocarpum, fell back to the level that characterizes the interval below the crumbly clay; the foraminifer, Ammonia, was hardly present, and the diatoms became again well preserved. Two features indicate, however, that the environment - while similar in many respects - was not the same as that before the crumbly-clay deposition. For the first time ostracods occurred (their appearance, or rather their absence in the underlying sediments, is not understood). Secondly, the diatom flora was essentially the same as in the crumbly clay, which suggests that, although the frustules appear well preserved, it is still a relict assemblage. This may be taken as evidence that the overall contribution of marine waters increased.

\section{A stratified lagoon again}

The characteristics of the unit on top of the homogeneous interval show that the restricted character of the environment further developed. The sediment is a 
laminated clay with a relatively high content of both organic carbon and sulphur. The dinoflagellate cyst assemblages show high variability and so do the foraminifers in the upper part of the interval. Without discussing the processes responsible, the high variability corresponds fairly well with a more restricted more lagoonal - environment.

The benthic organisms definitely show that the long-term deepening trend came to an end during deposition of the laminated clay. The mollusc, Turboella radiata balkei, reappears somewhat above the base of the interval, becoming gradually more abundant towards the top. The foraminiferal faunas initially do not show any change, but they, too, display a distinctly shallower signal towards the top.

The shallowing of the lagoon implies that the rate of sedimentation exceeded the rate of relative sea-level rise. With the Holocene depositional history in mind, this shallowing is attributed to significant slowing of sea-level rise and suggests that there is a causal link with the more restricted setting. A slower rate of sealevel rise means that less new space is available to accommodate sediments. As a result, shallow-marine areas started to shoal, thus favouring the development of effective barriers. The development of a barrier system in the sill area would no doubt seriously reduce the exchange between the lagoon and the open sea (Fig. 13a).

It is intriguing to consider precisely what processes actually account for the repeated change in the assemblages of both dinoflagellate cysts and foraminifers. Among the foraminifers, an Elphidium excavatum assemblage alternates with a Nonion germanicum assemblage. The contrast is great and the dominant species seem to exclude each other, which suggests that the assemblages represent two different, but adjoining environments. Because N. germanicum is a
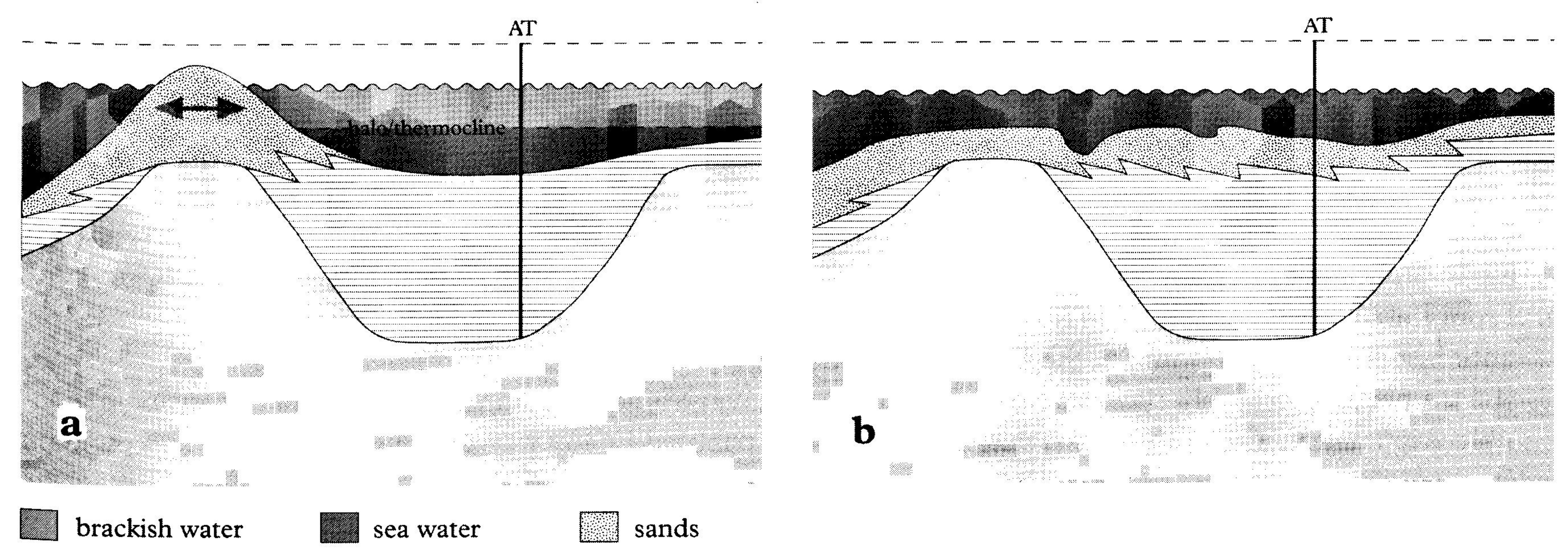

brackish-water species, it is thought that a salinity stratification again developed. The dinoflagellate signal cannot be related to specific parameters and, unfortunately, the diatoms do not offer any information about the surface waters. The foraminifer, Buccella frigida, returned as a common species, however, which suggests that cold waters were temporarily locked in the basin again.

\section{A tidal lagoon}

A completely different sedimentary regime prevailed during deposition of the upward coarsening, homogeneous clay that represents the late part of the Carpinus phase (regional zone E5). Both the lithology and the palaeontology show that the lagoon turned into an environment much more dynamic than previously during the Eemian (Fig. 13b). A maximum influence of the open sea is recorded by the dinoflagellate cysts, and the assemblages of benthic organisms are very similar to those found in the present-day Wadden Sea. It appears that the environment had changed into a large, tidally-affected mixosaline lagoon that received a significant supply of fresh water. Exchange with the open sea was no longer obstructed and the barrier system must have lost its significance.

Indeed, sedimentation was apparently controlled by tidal processes. The upward-coarsening of the sediment suggests that the basin infilled rapidly. The shallowing culminated in the deposition of the shell bed and the sands that make up the upper part of the Eemian sediments in the Amsterdam-Terminal sequence. These coarse sediments were deposited during the Picea phase (regional zone E6) and probably represent a channel facies. Clay pebbles occur and their pollen and diatom content indicate that the clay had been deposited on mudflats.

Fig. 13. The Amsterdam basin during deposition of (a) the Eemian upper laminated clay (regional pollen zone E5), and (b) the Eemian sand (late pollenzone E5). The main direction of water supply, the site of the Amsterdam-Terminal borehole and the present-day surface are indicated. West is on the left-hand side. 
The question as to what extent the regressive character of the succession can be related to a change in sea level must remain unanswered, because the sedimentary record as such does not provide the relevant information. We think that only the early part of the Picea phase is represented by sediment. In view of the topographically high position of this site, it seems unlikely that younger Eemian sediments have been preserved here (see Zagwijn, 1983). For reasons of simplicity, the present authors assume that the boundary between the Eemian and the Weichselian at $28.1 \mathrm{~m}$ represents a major hiatus.

\section{Conclusions}

The Amsterdam-Terminal borehole provides a section that could be sampled for analysis of pollen assemblages (Fig. 14), diatoms (Fig. 15), molluscs (Figs. 16 and 17), foraminifers (Fig. 18), dinoflagellates (Fig. 19), ostracods (Fig. 20) and heavy minerals (Fig. 21). Combination of these data has resulted in an integrated facies analysis, and subsequently in a detailed reconstruction of the depositional history of the Amsterdam basin following the retreat of the Saalian ice mass. Summarising, the following conclusions can be drawn.

1. The basin acted as a major sedimentary sink from the late Saalian to the late Eemian (Picea regional zone, E6). For some time during the transition from the Saalian glacial to the Eemian interglacial, sedimentation was interrupted at the site.

2. The early Eemian history is intimately connected with a rise of the sea level. In response to a rising groundwater table, a seepage lake developed during the Betula phase (E1), which steadily deepened. During the Quercus phase (E3), the lake changed gradually into a lagoon. Sedimentation could not keep pace with the rising sea level until at least the beginning of the Carpinus phase (E5). There is no information about a change in depth of deposition for the early part of E5, but before Carpinus pollen reached an apparent optimum, the basin began to shallow.

3. From the middle of the Corylus/Taxus phase (E4b) until just after the beginning of the Carpinus phase (E5), a peculiar crumbly clay was formed. A plausible explanation for the process that led to the crumbly appearance of the clay cannot be given. The clay represents an interval during which the lagoon was relatively well ventilated.

4. During the Eemian, the Amsterdam-Terminal site was situated at the interface between land and sea.
The specific setting renders the borehole great potential as a reference site for the last interglacial, because it links the palaeobiological record with sea-level history. To put it differently: the Amsterdam-Terminal sequence potentially links the climatic history of Western Europe with the global sea-level curve for the Eemian stage.

5. Sedimentation under interglacial conditions started earlier at the Amsterdam-Terminal than at the Amersfoort-1 site. As a consequence, the present authors prefer Amsterdam-Terminal as a reference site for the Eemian stage. The base of the Eemian stage is in Amsterdam-Terminal at $-62.05 \mathrm{~m}$ NAP.

6. The climate has not been discussed in detail. All palaeontological evidence corroborates the generally accepted view that a warmer climate prevailed in NW Europe during the Eemian stage in comparison to the Holocene. New evidence for a relatively warm climate for parts of the stage has been indicated by the ostracods and the dinoflagellate cysts.

7. High-latitude species are common in two specific intervals. The benthic foraminifer, Buccella frigida, and the planktic diatom, Thalassiosira nordenskioeldii, are locally abundant in the upper part of the Corylus regional zone (E4a) and the lower part of the Corylus/Taxus regional zone (E4b). The second interval includes part of the Carpinus optimum in the E5 regional zone, and only B. frigida is found there. It is not certain whether the absence of the diatom species in the second interval is of any consequence, because it concerns a relict assemblage that gives no information about the state of the surface waters. It is thought that winters were periodically extremely cold during the $\mathrm{E} 4 \mathrm{a} / \mathrm{E} 4 \mathrm{~b}$ transition and part of E5. This idea is, however, not supported by the climate analysis of Zagwijn (1996).

8. The Eemian sediments predate the Blake palaeomagnetic event.

9. The end of the last interglacial is not represented at the site of the borehole. The U/Th age of the uppermost part of the Eemian sequence is $\mathbf{1 1 8 . 2}$ $\pm 6.3 \mathrm{ka}$.

\section{Acknowledgements}

We would like to thank the colleagues who contributed in any way to the taking and the preparation of the cores and the preparation and analysis of the samples. Wim de Gans, Hanneke Gieske, Hans Huisman, Gerard Klaver and Ger de Lange are thanked for discussion and comments, and Phil Gibbard for correction of the English text. 
Karen Zonneveld (University of Bremen) provided helpful information concerning dinoflagellates, and Ben van Zanten (State University of Groningen) is thanked for his determination of the moss. Kai Beets (Free University of Amsterdam) supervised the radiometric dating. The drawings were skilfully drafted by Han Bruinenberg and Jos Rietstap.

This contribution is TNO report NITG 99-101-A.

\section{References}

Bijlsma, S., 1981. Fluvial sedimentation from the Fennoscandian area into the North-West European Basin during the Cenozoic. In: Van Loon, A.J. (ed.): Quaternary geology: a farewell to A.J. Wiggers. Geologie en Mijnbouw 60: 337-345.

Brockmann, C., 1928. Die Diatomeen im marinen Quartär Hollands. Abhandlungen der Senckenbergischen Naturforschenden Gesellschaft 41:3-73.

Cleve-Euler, A., 1951. Die Diatomeen von Schweden und Finnland. Kungliga Svenska Vetenskapsakademiens Handlingar, Fjärde Serien 2 (1): $163 \mathrm{pp}$.

Cleveringa, P., Meijer, T., Van Leeuwen, R.J.W., De Wolf, H., Pouwer, R. Lissenberg, T. \& Burger, A.W., 2000. The Eemian type locality at Amersfoort in the central Netherlands: redeployment of old and new data. In: Van Kolfschoten, Th. \& Gibbard, P.L. (eds.): The Eemian - local sequences, global perspectives. Geologie en Mijnbouw / Netherlands Journal of Geosciences 79: 197-216 (this issue).

Cremer, H., 1998. Die Diatomeen der Laptevsee (Arktischer Ozean): Taxonomie und biogeographische Verbreitung. Berichte zur Polarforschung 260: 1-205.

Dankers, P.H.M. \& Zijderveld, J.D.A., 1981. Alternating field demagnetization of rocks, and the problem of gyromagnetic remanence. Earth and Planetary Science Letters 53: 89-92.

De Gans, W., De Groot, Th. \& Zwaan, H., 1987. The Amsterdam glacial basin, a case study of a glacial basin in The Netherlands. In: Van der Meer, J.J.M. (ed.): Tills and glaciotectonics - Proceedings INQUA Symposium on the genesis and lithology of glacial deposits (1986). Balkema (Rotterdam): 205-216.

De Gans, W., Beets, D.J. \& Centineo, M.C., 2000. Late Saalian and Eemian deposits in the Amsterdam glacial basin. In: Van Kolfschoten, Th. \& Gibbard, P.L. (eds.): The Eemian - local sequences, global perspectives. Geologie en Mijnbouw / Netherlands Journal of Geosciences 79: 147-160 (this issue).

De Vernal, A., Londeix, L., Mudie, P.J., Harland, R., MorzadecKerfourn, M.T., Turon, J.-L. \& Wrenn, J.H., 1992. Quaternary organic-walled dinoflagellate cysts of the North Atlantic Ocean and adjacent seas: ecostratigraphy and biostratigraphy. In: Head, M.J. \& Wren, J.H. (eds.): Neogene and Quaternary dinoflagellate cysts and acritarchs. AASP Foundation (Dallas): 289-328.

De Wolf, H. \& Cleveringa, P., 1994. Eemian diatom floras in the Amsterdam glacial basin. In: Marino, D. \& Montresor, M. (eds.): Proceedings $13^{\text {th }}$ International Diatom Symposium (Biopress, Bristol): 489-505.

Edwards, L.E. \& Andrle, V.A.S., 1992. Distribution of selected dinoflagellate cysts in modern marine sediments. In: Head, M.J. \& Wren, J.H. (eds.): Neogene and Quaternary dinoflagellate cysts and acritarchs. AASP Foundation (Dallas): 259-288.

Foged, N., 1974. Fresh water diatoms in Iceland. Bibliotheca phycologica 15: 1-118.

Fretter, V. \& Graham, A., 1978. The prosobranch molluscs of Britain and Denmark, 4 Marine Rissoacea. Journal of Molluscan Studies 6: 153-241.
Grönlund, T., 1991. The diatom stratigraphy of the Eemian Baltic Sea on the basis of sediment discoveries in Ostrabothnia, Finland. Ph.D. thesis University of Helsinki: $131 \mathrm{pp}$.

Harland, R., 1983. Distribution maps of recent dinoflagellate cysts in bottom sediments from the North Atlantic Ocean and adjacent seas. Palaeontology 26: 321-387

Harting, P., 1874. De bodem van het Eemdal. Verslagen en Mededelingen van de Koninklijke Akademie van Wetenschappen, afdeling Natuurkunde II 8: 282-290.

Harting, P., 1875. Le système Eemien. Archives Néerlandaises des Sciences Exactes et Naturelles de Société Hollandaise de Sciences à Harlem 10: 443-454.

Jelgersma, S. \& Breeuwer, J.B., 1975. Toelichting bij de kaart glaciale verschijnselen gedurende het Saalien, 1:600.000. In: Zagwijn, W.H. \& Van Staalduinen, C.J. (eds.): Toelichting bij geologische overzichtskaarten van Nederland. Rijks Geologische Dienst (Haarlem): 93-103.

Jessen, K. \& Milthers, V., 1928. Stratigraphical and palaeontological studies of inter-glacial freshwater deposits in Jutland and northwest Germany. Danmarks Geologiske Undersøgelse II 48: 1-379.

Jorissen, F.J., 1988. Benthic foraminifera from the Adriatic Sea; principles of phenotypic variation. Utrecht Micropaleontological Bulletin 37: $176 \mathrm{pp}$.

Knudsen, K.-L., 1982. Foraminifers. In: Olausson, E. (ed.): The Pleistocene/Holocene boundary in south-western Sweden. Sveriges Geologiska Undersökning C 794: 148-177.

Knudsen, K.-L., 1985. Foraminiferal faunas in Eemian deposits of the Oldenbüttel area near Kiel Canal, Germany. Geologisches Jahrbuch A 86: 27-47.

Konert, M. \& Vandenberghe, J., 1997. Comparison of laser grain size analysis with pipette and sieve analysis: a solution for an underestimation of the clay fraction. Sedimentology 44:523-535.

Konradi, P. B., 1976. Foraminifera in Eemian deposits at Stensigmose, southern Jutland. Danmarks Geologiske Undersøgelse II 105: 1-55.

Lafrenz, H.R., 1963. Foraminiferen aus dem Riss-Würm-Interglazial (Eem) in Schleswig-Holstein. Meyniana 13: 10-46.

Langereis, C.G., Dekkers, M.J., De Lange, G.J., Paterne, M. \& Santvoort, P.J.M., 1997. Magnetostratigraphy and astronomical calibration of the last 1.1 Myr from an eastern Mediterranean piston core and dating of short events in the Brunhes. Geophysical Journal International 129: 75-94.

Ludwig, K.R. \& Titterington, D.M., 1994. Calculation of ${ }^{230} \mathrm{Th} / \mathrm{U}$ isochrons, ages, and errors. Geochimica et Cosmochimica Acta 58: 5031-5042.

Lutze, G.F., 1965. Zur Foraminiferen-Fauna der Ostsee. Meyniana 15: 75-142.

Mangerud, J., Sønstegaard, E. \& Sejrup, H.-P., 1979. Correlation of the Eemian (interglacial) stage and the deep-sea oxygen-isotope stratigraphy. Nature 277: 189-192.

Matoba, Y., 1970. Distribution of recent shallow water foraminifera of Matsushima Bay, Miyagi Prefecture, Northeast Japan. Scientific Reports of the Tohoku University, Sendai, $2^{\text {nd }}$ series 42: 1-85.

Munsterman, D.K. \& Kerstholt, S.J., 1996. Sodium polytungstate, a new non-toxic alternative to bromoform in heavy liquid separation. Review of Palaeobotany and Palynology 91: 417-422.

Nowaczyk, N.R., Frederichs, T.W., Eisenhauer, A. \& Gard, G., 1994. Magnetostratigraphic data from late Quaternary sediments from the Yermak Plateau, Arctic Ocean: Evidence for four geomagnetic polarity events within the last $170 \mathrm{Ka}$ of the Brunhes chron. Geophysical Journal International 117: 453-471.

Osmond, J.K., May, J.P. \& Tanner, W.F., 1970. Age of the Cape Kennedy barrier-and-lagoon complex. Journal of Geophysical Research 75: 469-479. 
Paasche, E., 1975. Growth of the plankton diatom Thalassiosira nordenskioeldii Cleve at low silica concentrations. Journal of Experimental Marine Biology and Ecology 18: 173-183.

Rasmussen, E., 1973. Systematics and ecology of the Isefjord marine fauna. Ophelia 11:1-495.

Reinders, J. \& Hambach, U., 1995. A geomagnetic event recorded in loess deposits of the Tönchesberg (Germany): identification of the Blake magnetic polarity episode. Geophysical Journal International 122: 407-418.

Stoermer, E.F., 1980. Characteristics of benthic algal communities in the upper Great Lakes. U.S. Environmental Protection Agency, Ecological Series EPA 600/3-80-073: 72 pp.

Uffenorde, H., 1982. Zur Gliederung des klastischen Holozäns im mittleren und nordwestlichen Teil der Deutschen Bucht (Nordsee) unter besonderer Berücksichtigung der Foraminiferen. Eiszeitalter und Gegenwart 32: 177-202.

Van den Berg, M.W. \& Beets, D.J., 1987. Saalian glacial deposits and morphology in The Netherlands. In: Van der Meer, J.J.M. (ed.): Tills and glaciotectonics. Proceedings INQUA Symposium on the genesis and lithology of glacial deposits (1986). Balkema (Rotterdam): 235-251.

Van der Wateren, F.M., 1985. A model of glacial tectonics, applied to the ice-pushed ridges in the central Netherlands. Bulletin of the Geological Society of Denmark 34: 55-74.

Van Hoof, A.A.M. \& Langereis, C.G., 1991. Reversal records in marine marls and delayed acquisition of remanent magnetiza- tion. Nature 351: 223-225.

Van Voorthuysen, J.H., 1957. Foraminiferen aus dem Eemien (Riss-Würm-Interglazial) in der Bohrung Amersfoort I (Locus typicus). Mededelingen Geologische Stichting 11:28-39.

Zagwijn, W.H., 1961. Vegetation, climate and radiocarbon datings in the Late Pleistocene of The Netherlands, Part I: Eemian and Early Weichselian. Mededelingen Geologische Stichting 14:1545

Zagwijn, W.H., 1974. Palaeogeographic evolution of The Netherlands during the Quaternary. Geologie en Mijnbouw 53: 369385.

Zagwijn, W.H., 1975. Indeling van het Kwartair op grond van veranderingen in vegetatie en klimaat. In: Zagwijn, W.H. \& Van Staalduinen, C.J. (eds.): Toelichting bij geologische overzichtskaarten van Nederland. Rijks Geologsiche Dienst (Haarlem): 109-114.

Zagwijn, W.H., 1983. Sea-level changes in The Netherlands during the Eemian. Geologie en Mijnbouw 62: 437-450.

Zagwijn, W.H., 1992 Migration of vegetation during the Quaternary in Europe. Courier Forschungs- Institut Senckenberg 153: 9-20.

Zagwijn, W.H., 1996. An analysis of Eemian climate in western and central Europe. Quaternary Science Reviews 15: 451-469.

Zandstra, J.G., 1978. Einführung in die Feinkiesanalyse. Der Geschiebesammler 12:21-38. 
Figures 14-21 on pages 26-36 


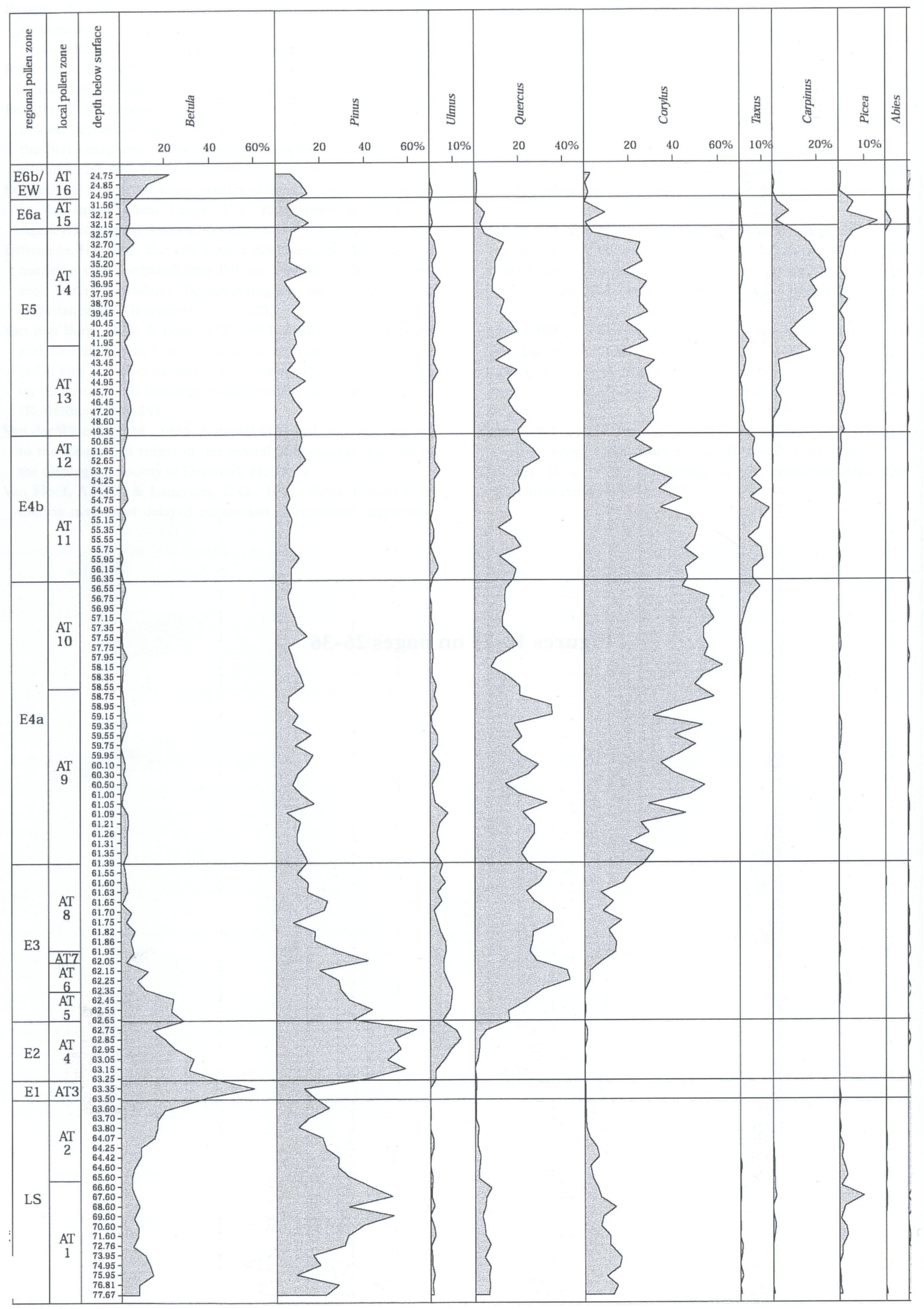




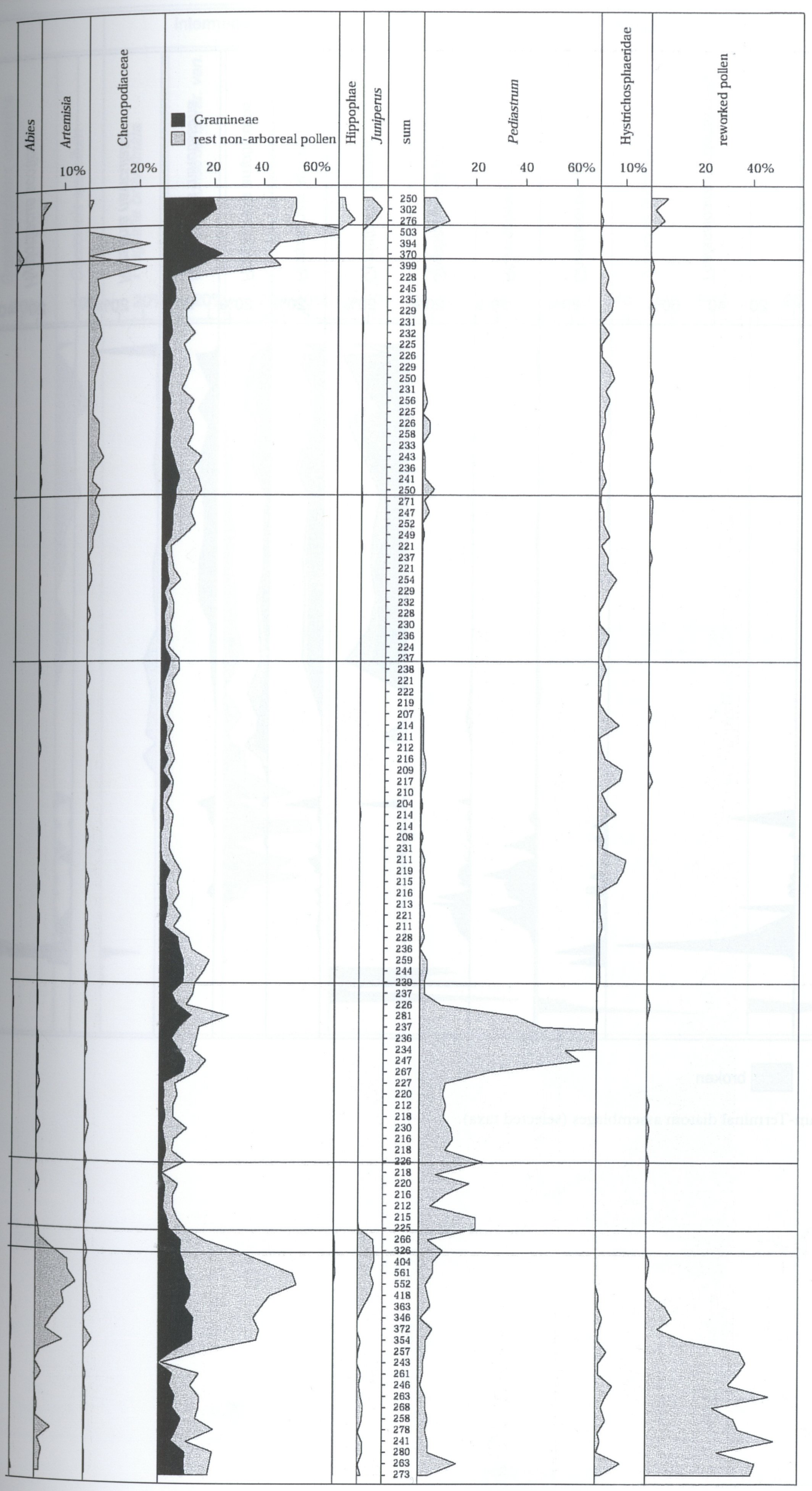

Fig. 14 (p. 186-187). Amsterdam-Terminal pollen assemblages (selected taxa). 

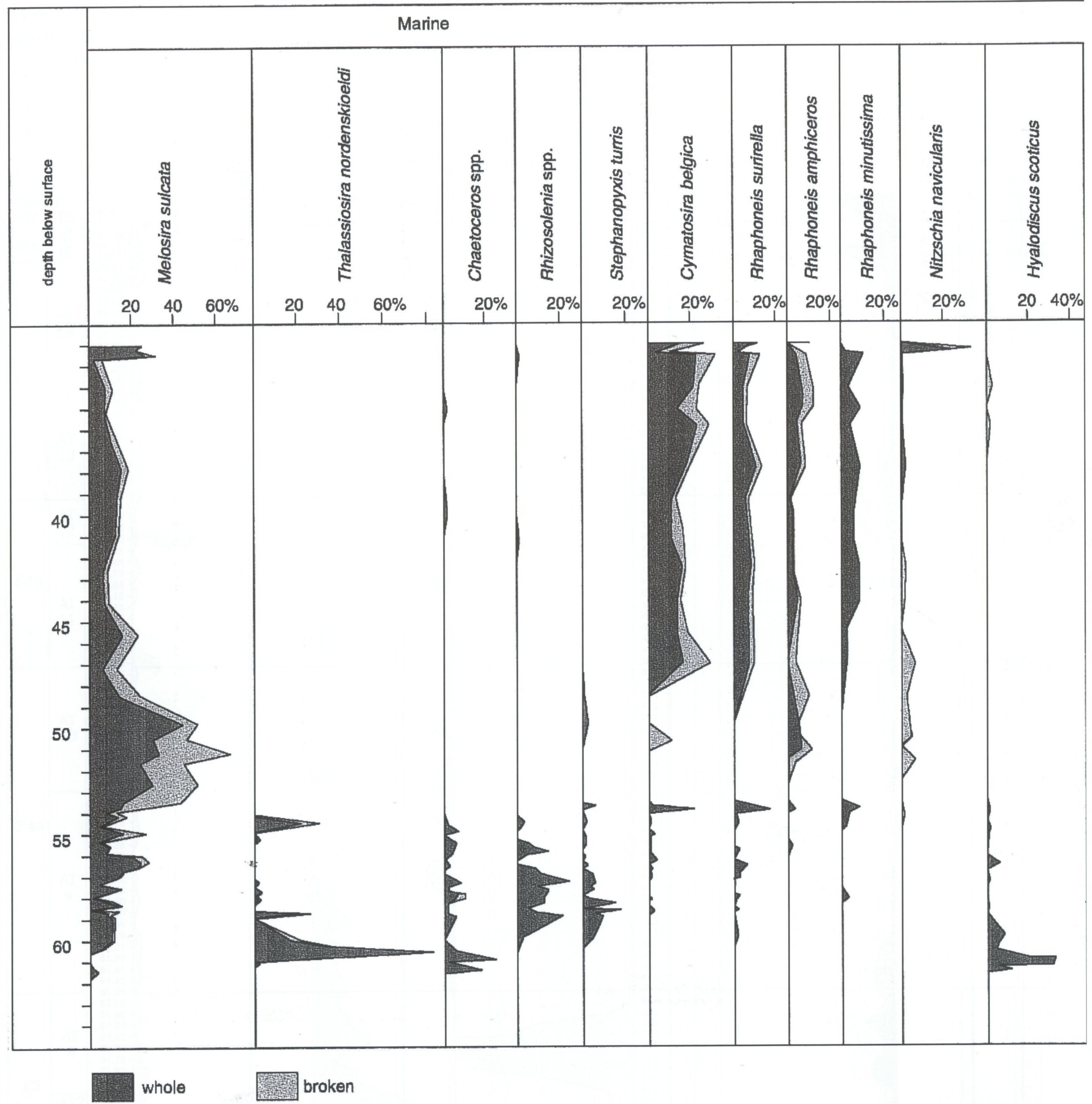

Fig. 15 (p. 188-189). Amsterdam-Terminal diatom assemblages (selected taxa). 


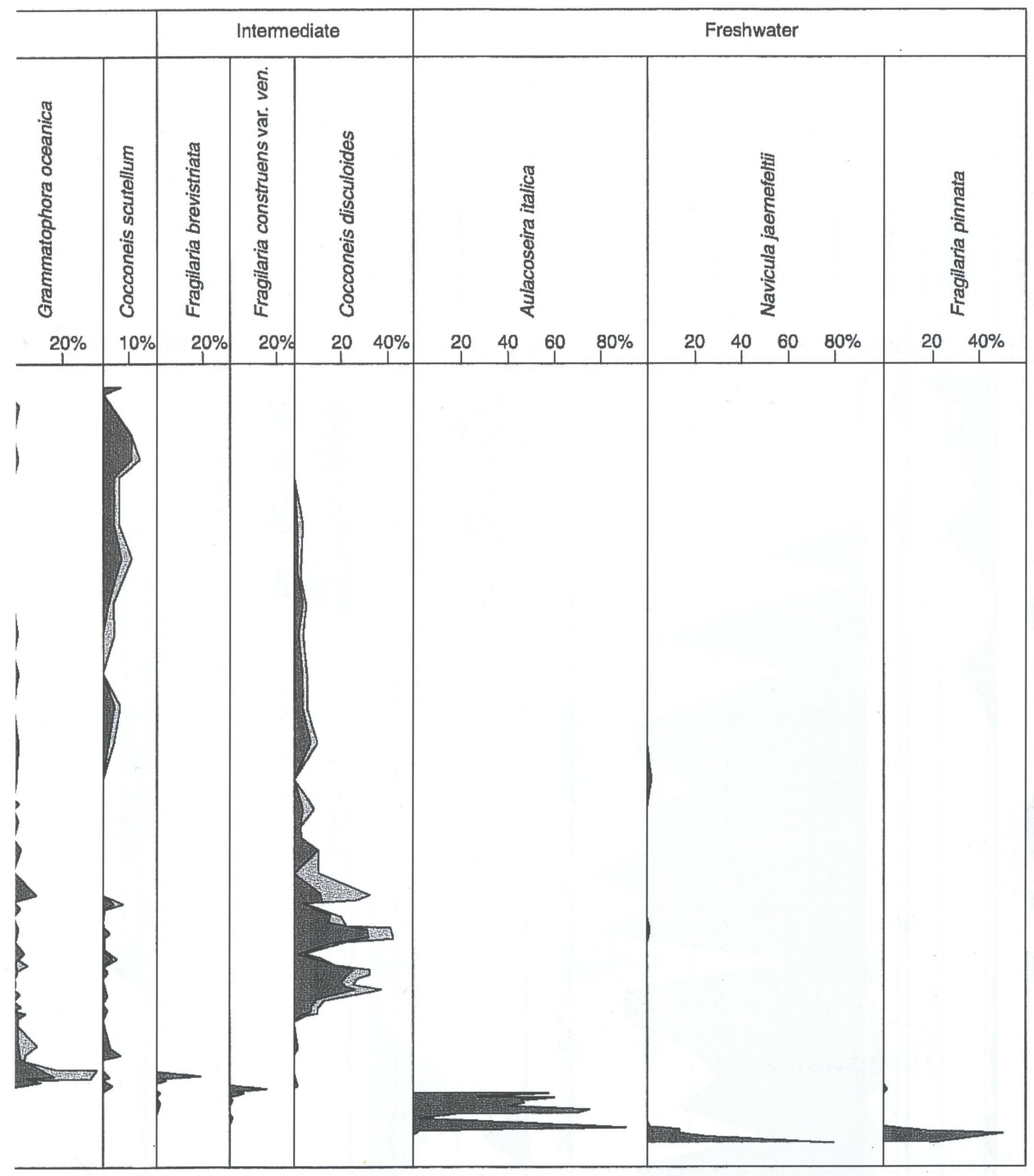




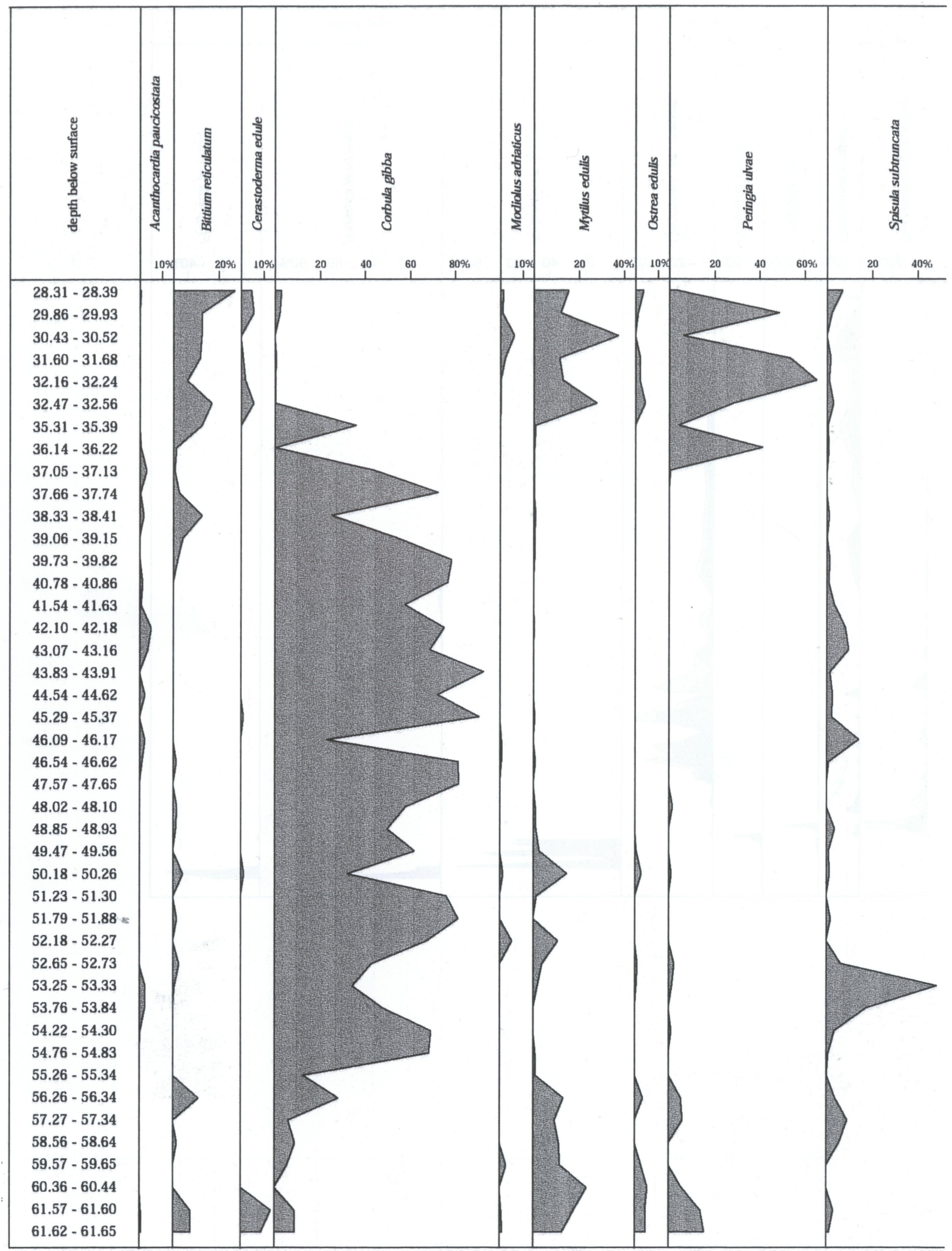

Fig. 16 (p. 190-191). Amsterdam-Terminal mollusc assemblages (selected taxa). 


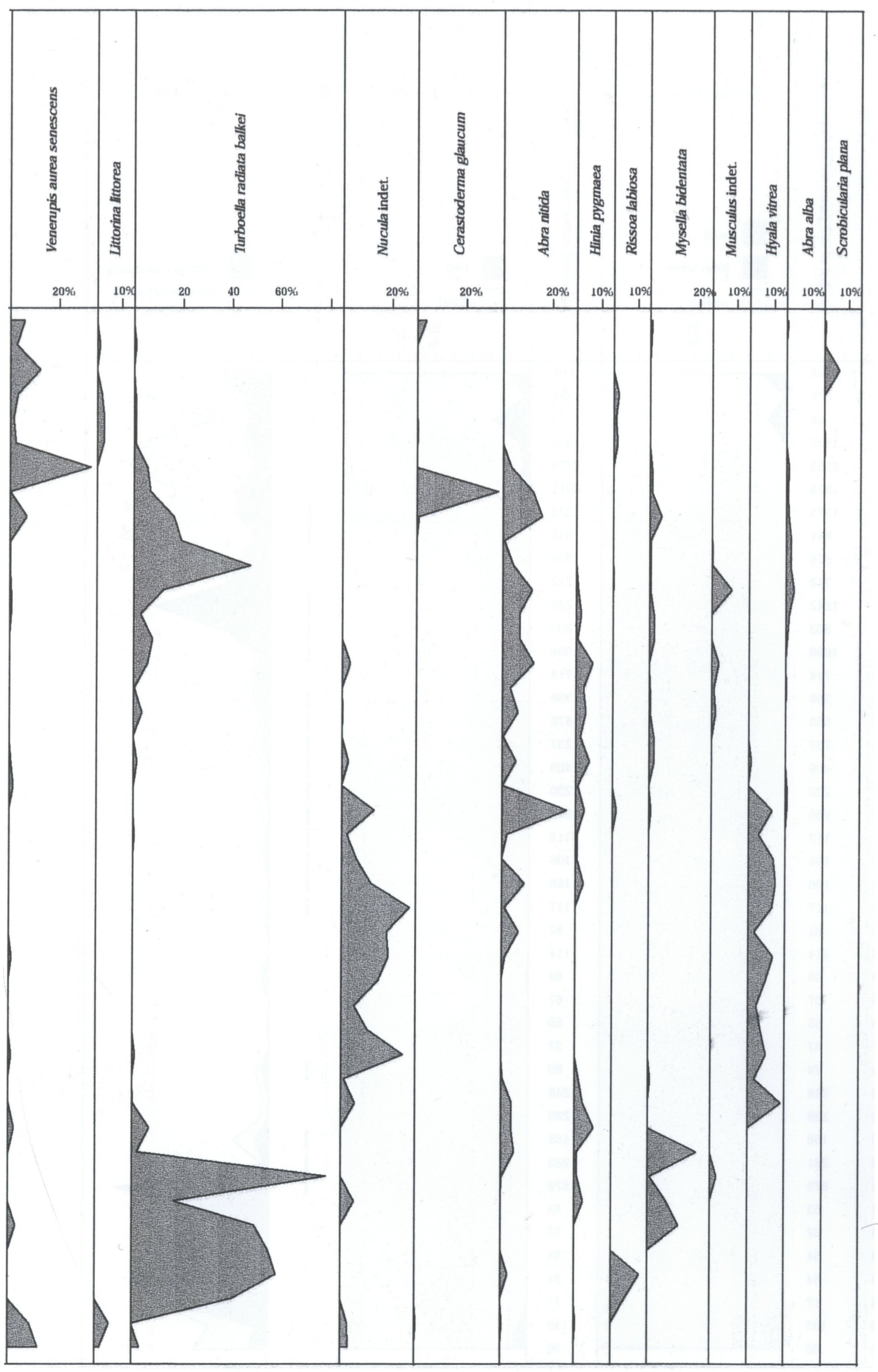




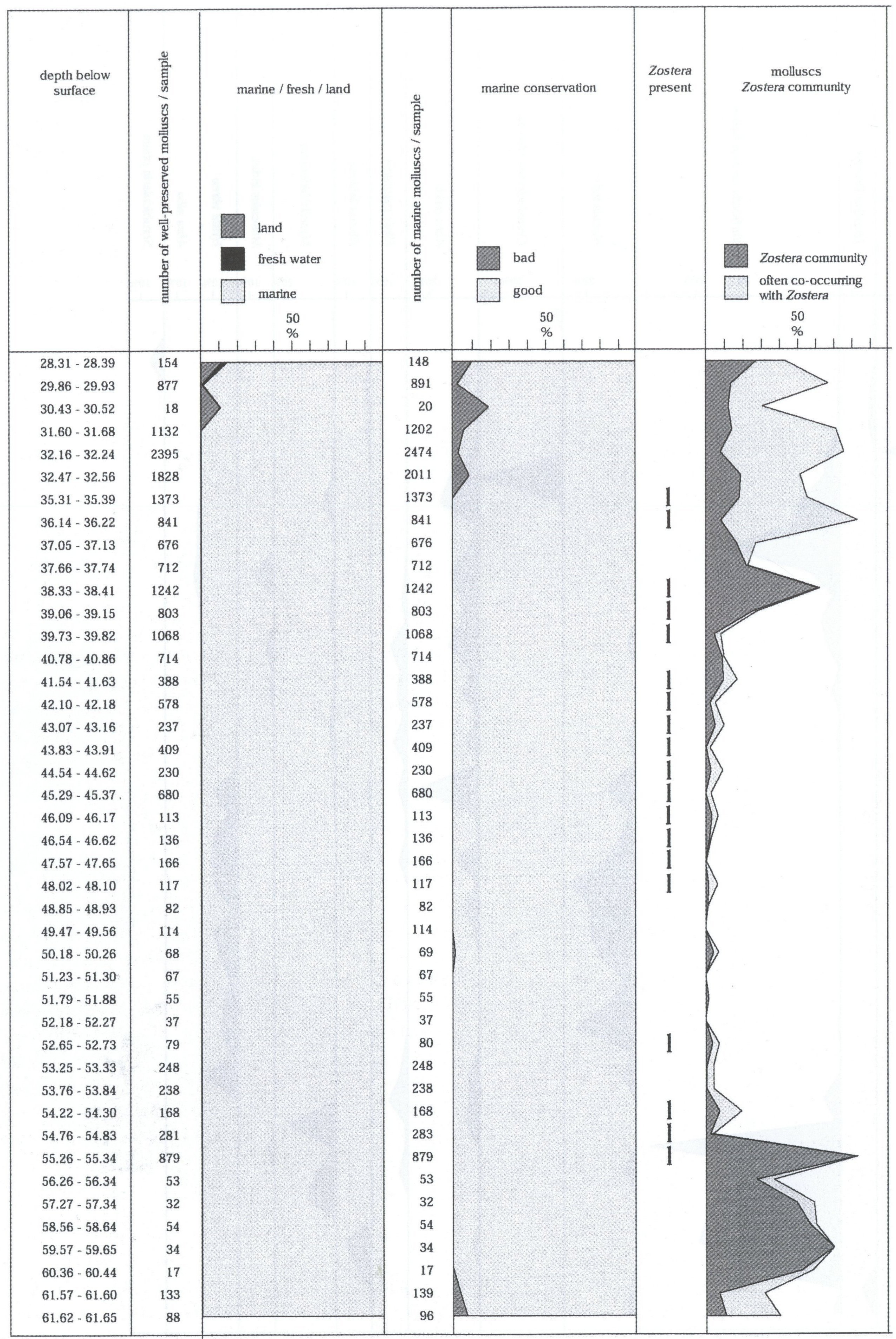

Fig. 17 (p. 192-193). Amsterdam-Terminal mollusc ecograms. 


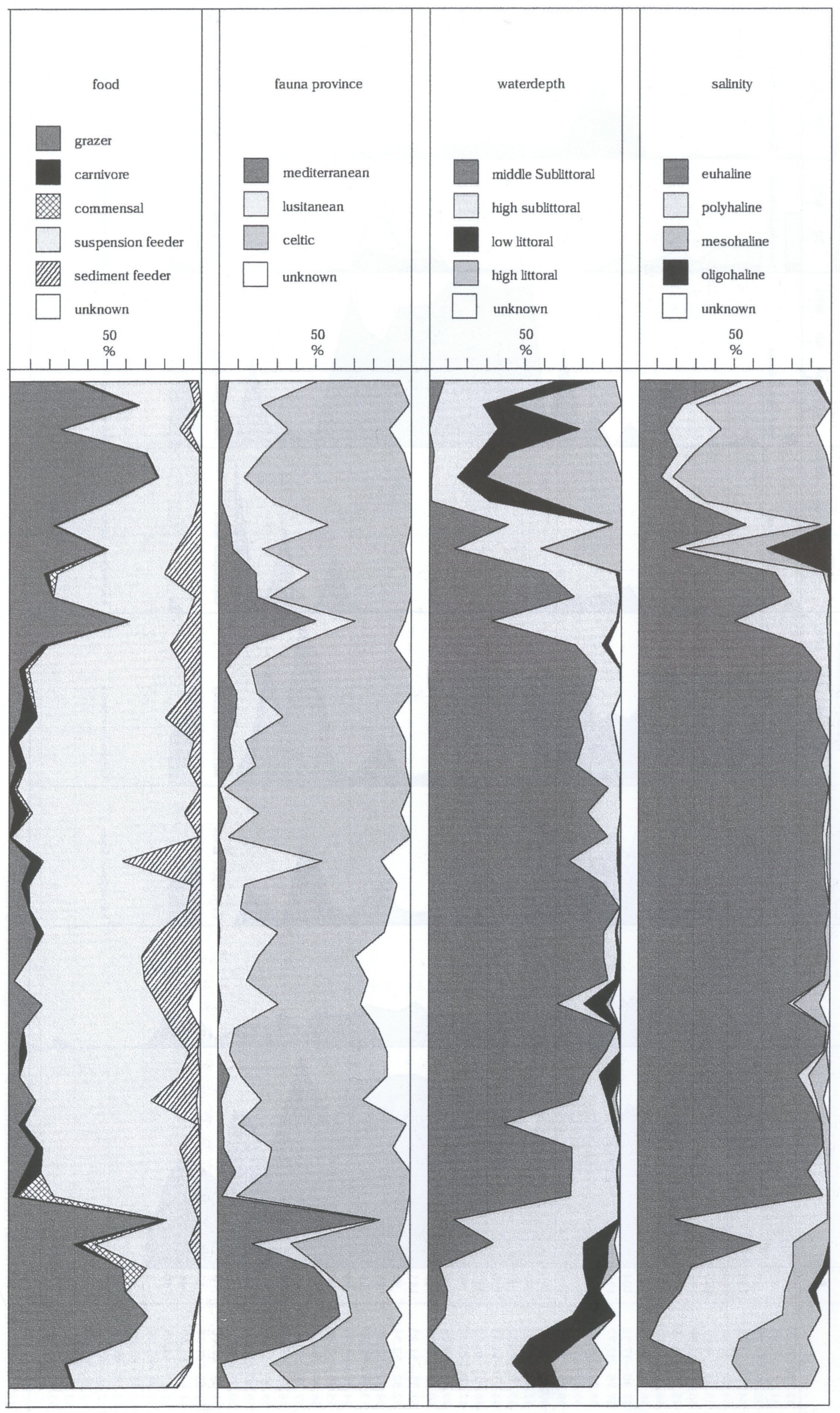




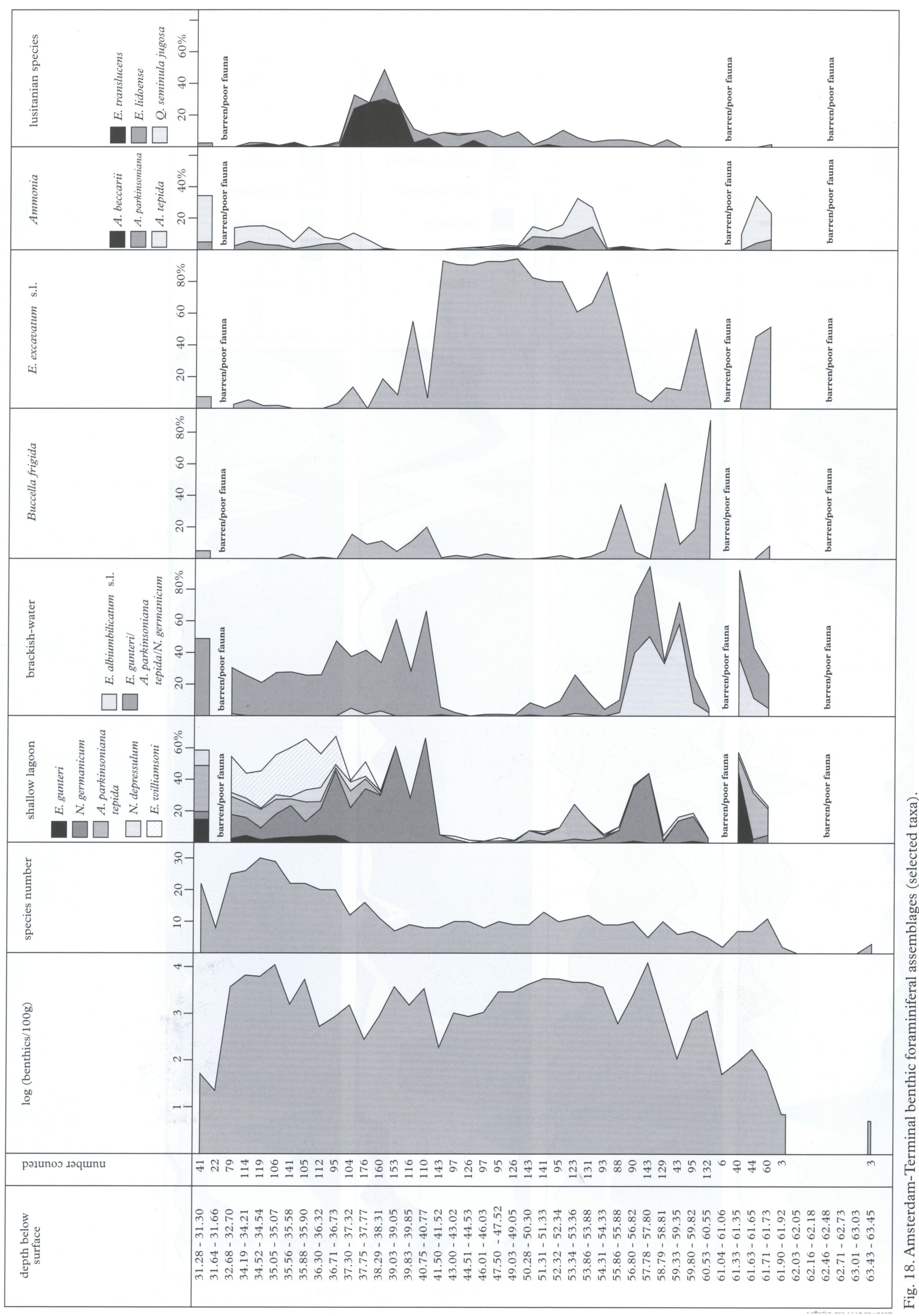




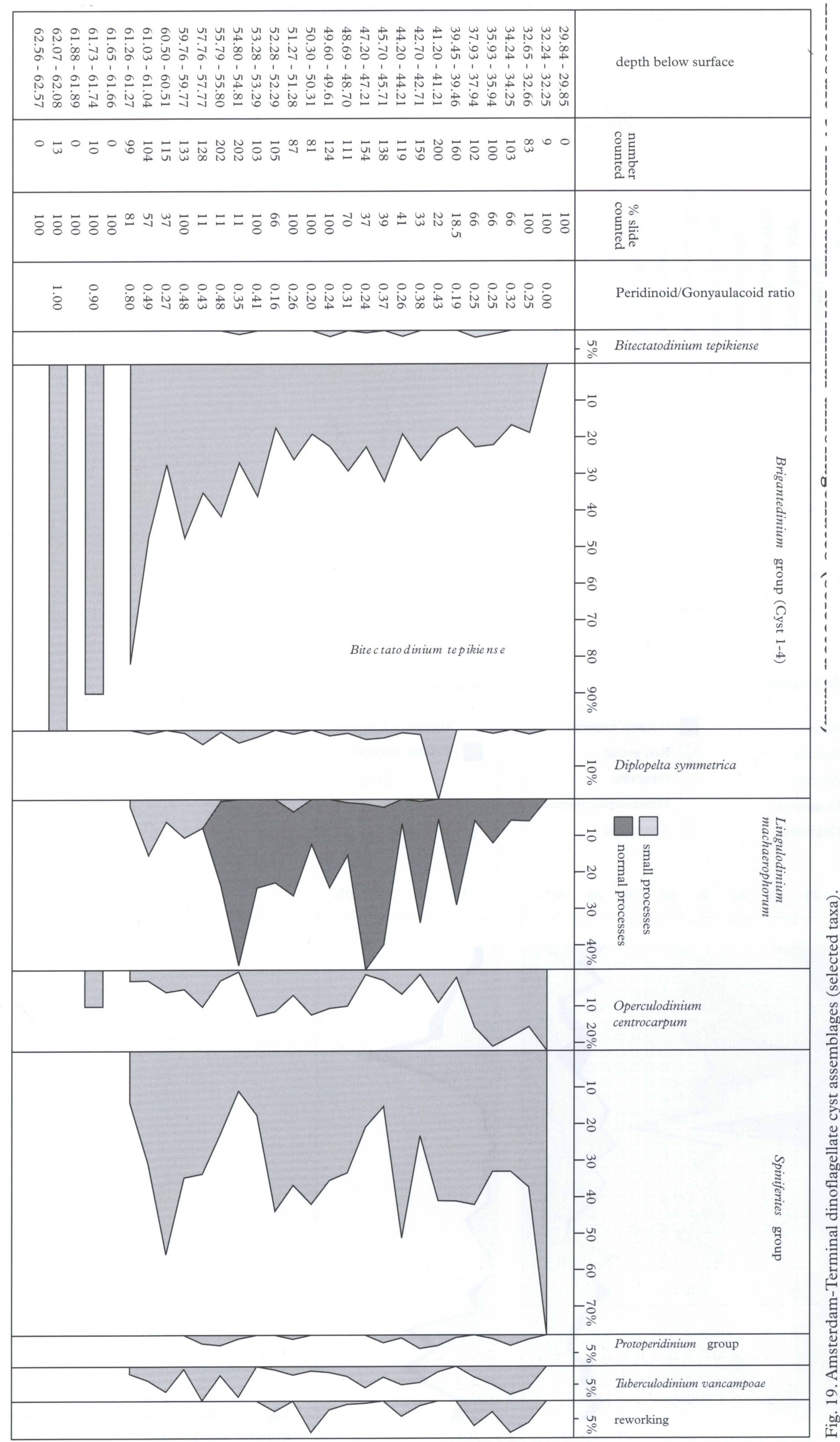




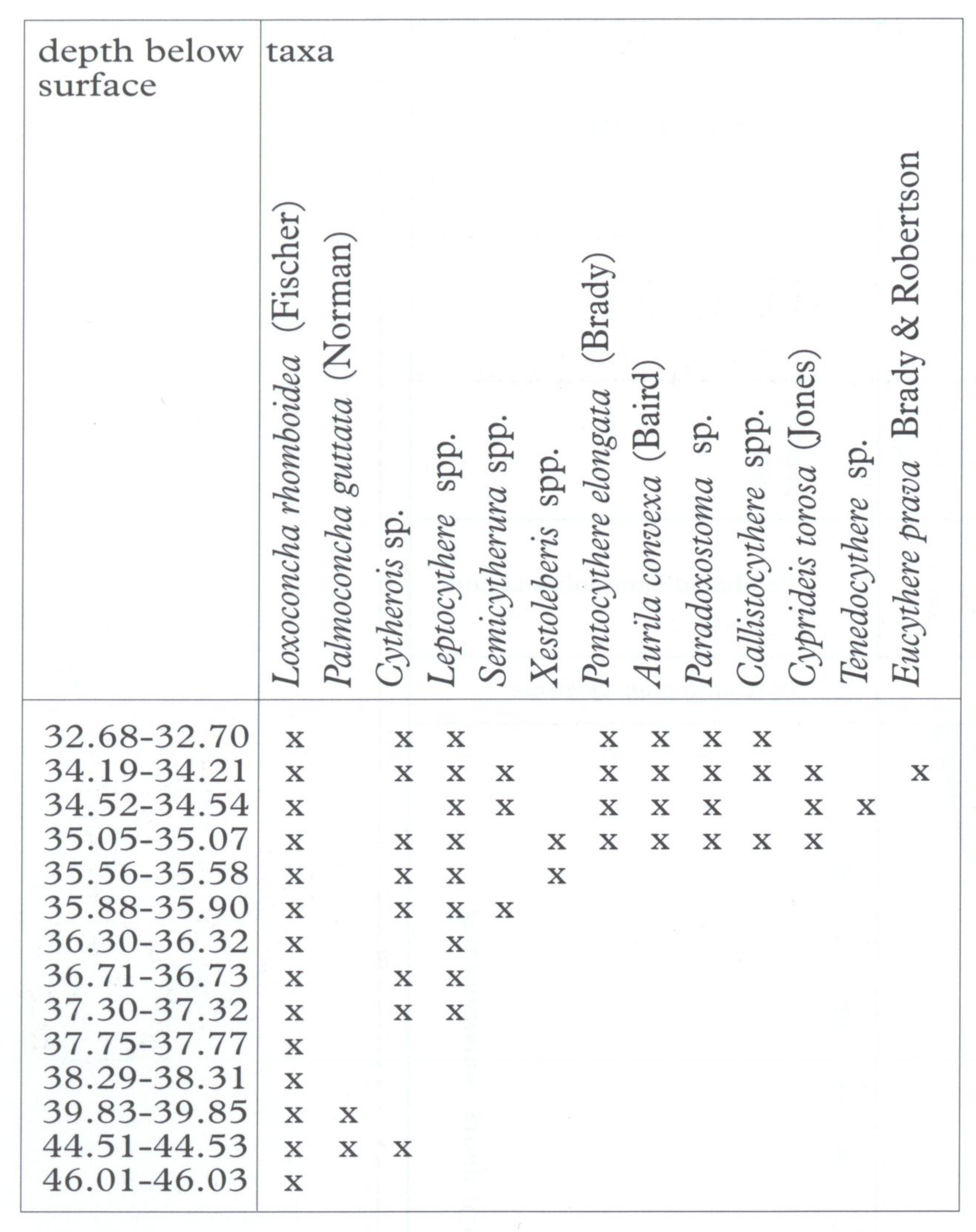

Fig. 20. Amsterdam-Terminal ostracod assemblages.

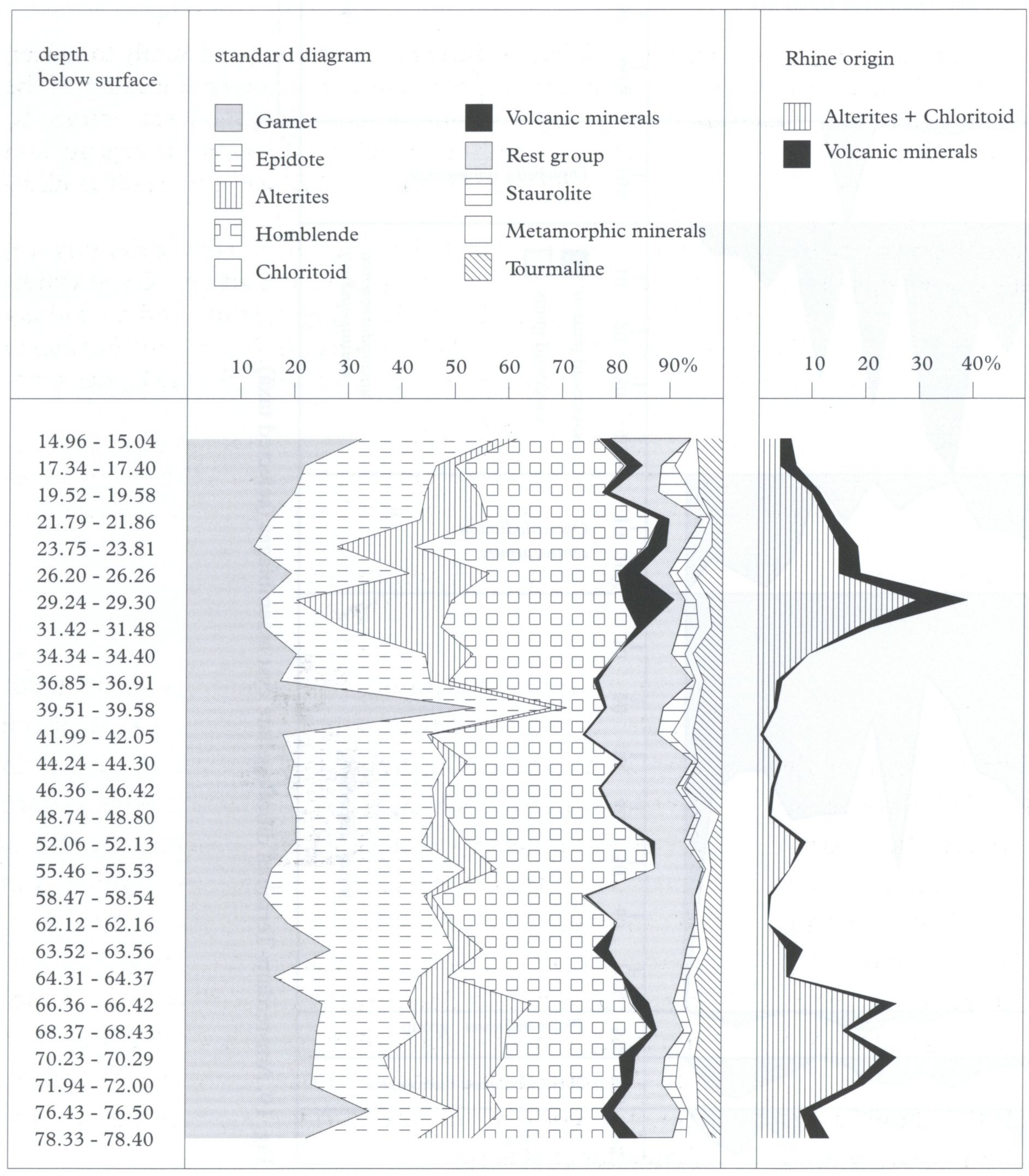

Fig. 21. Amsterdam-Terminal heavymineral assemblages. 